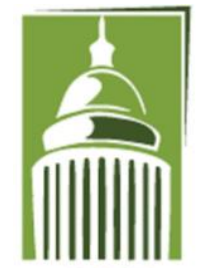

AR F

\section{Global Proceedings Repository}

American Research Foundation

ISSN 2476-017X

Available online at http://proceedings.sriweb.org

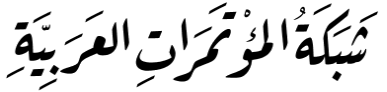

http://arab.kmshare.net/

First Forum on Gifted Education in Lebanon

$$
27 \text { تشرين الأول } 2017 \text { فندق ديونز - فردان، بيروت، الجمهورية اللبنانية }
$$

http://www.taaheel.net/conferences/

\title{
The Need for a Program Model for the Gifted and Talented Students: Raising Community Awareness, Identification, and Effective Intervention in Southern Lebanese Schools
}

\begin{abstract}
Amena Allouch
Abstract: Gifted and talented students are learners with outstanding creative abilities, and are capable of high performance in subject matters. They require special care and services beyond those provided normally by the regular Lebanese educational program. This study aims to examine the community's awareness towards the gifted and talented students, and the capability of teachers to identify them and provide them with a program model. Teachers from Safir High School and Generations High School were asked to answer a questionnaire; a structured interview was carried out with the schools' principals; and a battery of developmental assessment test was administered to 55 students nominated by their schools as gifted and talented. The study showed that $64 \%$ of the teachers agreed that gifted and talented students need a special program that fits their abilities. The principals differentiated the gifted and talented students' needs from the other students and highlighted the need for programs that target them. Moreover, the battery of developmental assessment test showed that only one nominated student was gifted. This study designed a program model which increases students' performance, limits their problems, and allows them to grow and express their abilities normally. This study recommends to aware and train teachers on how to identify gifted and talented students and how to implement the program model in southern Lebanese schools.
\end{abstract}

Keywords: Gifted and Talented, Students, Schools, Program, Lebanon 


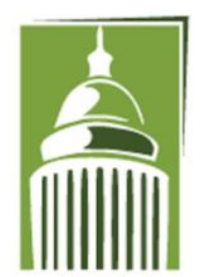

ARF

\section{Global Proceedings Repository \\ American Research Foundation}

ISSN 2476-017X

Available online at http://proceedings.sriweb.org

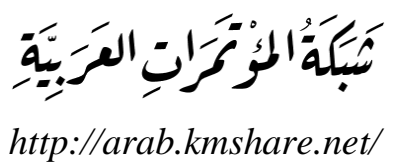

http://arab.kmshare.net/

\section{Introduction}

All students require opportunities to learn and grow, and to be challenged to strive for excellence. Students with exceptional talents and learning potentials have needs that require specific knowledge and attention. With careful nurturing and appropriate education, gifted students have the potential to make a unique contribution to their communities and the world. Otherwise, their academic growth, creative potential, enthusiasm for educational success, eventual professional achievements and substantial contributions to society will be lost (Davis \& Rimm, 2004).

Programs dedicated to the gifted are virtually non-existent in Lebanon. While some private schools offer some enrichment programs to high-achieving students, these programs are limited in content, and represent attempts to nurture the talent and ability of students with high grade-point averages through a variety of enhancement activities (Sarouphim, 2009). It is true that some gifted students are high achievers, but not all of them are. One of the biggest issues today for both gifted and regular education is underachievement (McCoach \& Siegle, 2003). Often the reasons of underachievement are complex and have more to do with issues outside of school such as stress, instability, family situations and societal values. However, the school has the ability to significantly figure out the reasons.

Now, schools in Lebanon - both public and private - follow a unified national curriculum mandated by the Ministry of Education. The Center for Educational Research and Development CERD (1995), emphasized that nurturing to students with special needs should be obligatory. Provisions offer support services and remedial classes to students with learning disabilities, but exclude services of any sort to the gifted ones. In addition to that, the Public Law number 220, which was approved by the Lebanese Parliament in May 2000, provided a legislative framework for people with disabilities(Wehbi, 2006, p. 323). Article 59 of the Law guarantees the right to equal educational and learning opportunities for all including the disabled. Moreover, article 60 asserts that a disability should not restrict access to any educational institution or setting in Lebanon. However, there exists no mention of the education of gifted students in the Lebanese law. Clearly, the scope of special education in Lebanon is limited to students with disabilities, as neither the Lebanese law nor the revised national curriculum has made any stipulations concerning the issues and matters of educating gifted students in Lebanese schools. In other words, the subject of educating gifted learners is neither encouraged nor discouraged in the Lebanese national curriculum; it is simply ignored (Wehbi, 2006).

Gagné (1991) differentiates between the concept of gifted and that of talented by defining giftedness as above average competence in human ability, and talent as above- 


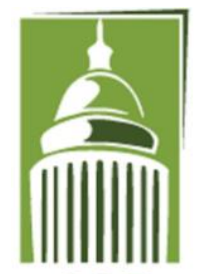

ARF

\section{Global Proceedings Repository \\ American Research Foundation}

ISSN 2476-017X

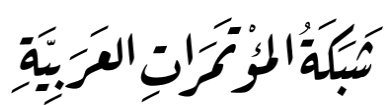

http://arab.kmshare.net/

Available online at http://proceedings.sriweb.org

average performance in a particular field. Giftedness refers to human aptitudes such as intellectual or creative abilities. Talent, however, is demonstrated in an area of human activity such as mathematics, literature or music.

Gagné (1995), in the Differentiated Model of Giftedness and Talent (DMGT), clearly distinguishes between giftedness and talent (see figure 1 below). Giftedness is the possession and use of untrained and spontaneously expressed natural abilities, in at least one ability domain, to a degree that places an individual in at least the top 10 percent of age peers. He identifies 4 domains representing giftedness: intellectuality, creation, socioaffectiveness and sensory-motor. Talent designates the superior mastery of systematically developed abilities or skills and knowledge in at least one field of human activity to a degree that places an individual at least among the top 10 percent of age peers who are active in that field. These skills include: academics, arts, business, leisure, social actions, sports and technology. Catalysts (either positive or negative) for their development include milieu, people, provisions and events (Gagné, 1995).

\begin{tabular}{l}
\hline Giftedness Top \\
\hline NATURAL ABILITIES (NAT) \\
DOMAINS \\
Intellectual (IG) \\
Fluid reasoning (induct./deduct.), \\
cristallized verbal, spatial, \\
memory, sense of observation, \\
judgment, metacognition. \\
Creative (CG) \\
Inventiveness (problem-solving), \\
imagination, originality (arts), \\
retrieval fluency. \\
Socioaffective (SG) \\
Intelligence (perceptiveness). \\
Communication (empathy, tact). \\
Influence (leadership, persuasion). \\
SensoriMotor (MG) \\
S: visual, auditory, olfactive, etc. \\
M: strength, endurance, \\
reflexes, coordination, etc. \\
\end{tabular}

\section{CATALYSTS}

INTRAPERSONAL (IC)

Physical: characteristics, handicaps, health, etc.

Motivation: needs, interests, values, etc.

Volition: will-power, effort, persistence.

Self-management: concentration, work habits, initiative, scheduling, etc. Personality: temperament, traits, wellbeing, self-awareness \& esteem,

DEVELOPMENTAL PROCESS Informal/formal learning \& nunatiaina $/ 1 n$

\section{ENVIRONMENTAL $(E C)$}

Milieu: physical, cultural, social, familial, etc.

Persons: parents, teachers, peers, mentors, etc.

Provisions: programs, activities, services, etc.

Events: encounters, awards, accidents, etc.
Talent Top 10\%

\section{SYSTEMATICALLY}

DEVELOPED

SKILLS (SYSDEV)

FIELDS

(relevant to school-age youths) Academics: language, science, humanities, etc.

Arts: visual, drama, music, etc. Business: sales, entrepreneurship, management, etc.

Leisure: chess, video games, puzzles, etc.

Social action: media, public office, etc.

Sports: individual \& team.

Technology: trades \& crafts, electronics, computers, etc. 


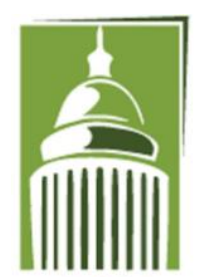

A R F

\section{Global Proceedings Repository \\ American Research Foundation}

ISSN 2476-017X

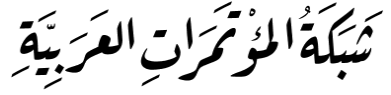

http://arab.kmshare.net/

Available online at http://proceedings.sriweb.org

Apart from intelligence, other factors like intrapersonal characteristics (e.g., motivation, stress) and environmental conditions (e.g., quality of teaching, family) are considered to be essential for the manifestation of gifted behavior. Nowadays, most researchers agree that giftedness is a multidimensional concept (Feldhusen \& Jarwan, 2000; Gagné, 1993, 2000; Heller, 1990, 1991; Ziegler \& Heller, 2000). Consistent with this idea, highly intelligent students need to have certain optimal intrapersonal characteristics and environmental conditions in order to express their talents in performance.

\section{Purpose of the Study}

The purpose of this study is to present a program model for the gifted and talented students. The model consists of three phases including: raising community awareness, adopting valid identification measures, and applying effective intervention in schools in South Lebanon.

An important consideration is to embed the model in non-traditional views of intelligence and giftedness, so that programs are diversified and identification is not limited to high scores on standardized tests. As such, the model is based on Discover, a non-traditional system for identifying and educating gifted learners. Research is needed to determine the effectiveness of such a model in Lebanon. The model could be emulated by other Arab countries where it can be adopted and adapted to the unique needs and particulars of each culture.

\section{Need of the Study}

Gifted and talented learners are identified as those outstanding learners in creative ability, and are capable of high performance in an area of human activity. They require differentiated educational programs and services beyond those provided normally by the regular school programs (Heward, 2006). The study of giftedness has been marked by an evolution in definitions, programs, services, and professional interest (Friend, 2008). Over the past 10 years, students who were not learning successfully were targeted for special attention. Sadly, at the same time, the needs of the most capable students have been overlooked. One reason for this neglect is the ability of gifted students to have high scores on assessments, which has led to the erroneous assumption that they are learning well. Another reason for ignoring their needs is that many educational leaders have misunderstood the research on role modeling which means that some gifted students should be present in all classrooms to facilitate the forward progress for other students. Although students who struggle to learn can benefit from mixed-ability classes, they have plenty of positive role models of capable students who function well at the appropriate grade level, but not gifted ones. The discrepancy in learning abilities between students who struggle to 


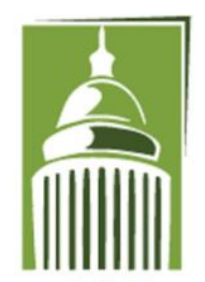

ARF

\section{Global Proceedings Repository \\ American Research Foundation}

ISSN 2476-017X

Available online at http://proceedings.sriweb.org

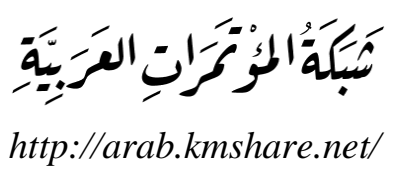

http://arab.kmshare.net/

learn and gifted ones is simply too wide to facilitate the positive role modeling (Schunk, 1987).

Teachers are expected to create numerous differentiating adjustments for lowachieving students by modifying the amount of work, depth, complexity, and content of the curriculum, and by linking the students' learning styles and interests to the prescribed learning tasks. Teachers avidly follow the progress of these students' learning and look for evidence that these students are moving forward indeed.

However, gifted students, whose natural learning abilities place them as far from average as their underachieving classmates, are treated equally to those who struggle to learn. Southern Lebanese schools lack special programs for gifted and talented students, which means that teachers are submitting the same types of differentiation for all students. Teachers are managing their classrooms as if their students have equal abilities. Even if the gifted students could take the same assessment as their classmates and score at or above the average grade, these assessment tools will not commensurate with the abilities of high able students. That means that the learning progress of these students is not adequately measured.

\section{Significance of the Study}

All pupils are entitled to an education that takes them beyond the minimal basic skills and stretches them to develop their abilities as best as they can. If teachers do not expect a student who is a talented sportsman to play less than his best because his age peers are not as advanced, then should gifted or talented students quietly wait until the rest of the class has finished or to complete more of the same task to fill the time (Winstanley, 2004)?

This question should be reflected upon by each educator who genuinely cares about his students and their progress. That is because if these gifted and talented students are simply ignored, then boredom would often turn to frustration, underachievement, and disaffection will appear in the learning process. The educational system is responsible to provide an appropriate level of challenge for students of all abilities, not only for those who may be classified under the traditional bracket of "special needs".

\section{Scope of the Study}

A sample of teachers answered a closed ended questionnaire and a structured interview was performed with Safir and Generations High Schools' principals in order to study the teachers' awareness, identification of gifted students, and the need for a program model. After analyzing the result, a seminar took place in order to increase teachers' consciousness, and aware them about how to define the gifted and talented students, list their properties, and how to identify them. A program model was designed to be 


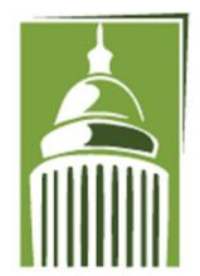

ARF

\section{Global Proceedings Repository \\ American Research Foundation}

ISSN 2476-017X

Available online at http://proceedings.sriweb.org

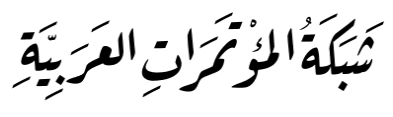

http://arab.kmshare.net/

compatible to the giftedness and talent of each student. An invitation was directed to many schools to nominate the gifted and talented students they believe they have. 55 students were nominated. A battery of developmental assessment (BDA) test was used to identify the abilities of these students, discover their various needs, and provide appropriate Individual Educational Plans (IEPs).

\section{Research Question}

- Do Southern Lebanese schools need a program model for gifted and talented students?

\section{Definition of Terms}

Gifted and talented students. The term "gifted and talented" when used in respect to students, children, or youth means students, children, or youth who give evidence of high performance capabilities in areas such as intellectual, creative, artistic, or leadership capacity, or in specific academic fields which require special services or activities. Gifted children may develop differently; their minds are often ahead of their physical growth, and specific cognitive and social-emotional functions can develop unevenly. Some gifted children with exceptional abilities may not demonstrate outstanding levels of achievement due to environmental circumstances such as limited opportunities to learn as a result of poverty, discrimination, or cultural barriers due to physical or learning disabilities, or due to motivational or emotional problems (Gagné, 1991).

Program model.A coordinated and comprehensive structure of informal and formal services provided on a continuing basis and intended to nurture gifted learners (National Association for gifted students, 2011).

Creative potential. Creativity can be defined as the ability to produce original work that fits the context and responds to task constraints (Sternberg \& Lubart, 1995).

High-achieving. High achievers are those who achieve a goal. In school, a high achiever would be a student who gets high marks, and good grades. High achievers do the work that is required and do it well. They tend to be well-organized, and have good timemanagement skills that they use to produce neat and tidy work on time (Szabos, 1989).

Underachievement. Underachievement is content and situation specific; those who may not be successful at school, for example, are often successful in outdoor activities such as sports, music or after-school jobs. Also, labeling a student as an underachiever ignores the positive outcome of those areas in which the student does succeed; it therefore makes more sense to label the area of underachievement, and not the student himself (Delisle and Berger, 1990). 


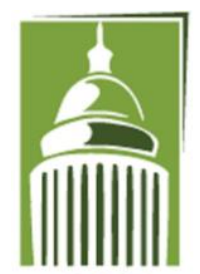

ARF

\section{Global Proceedings Repository \\ American Research Foundation}

ISSN 2476-017X

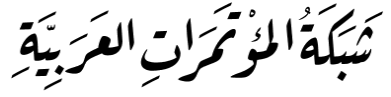

http://arab.kmshare.net/

Available online at http://proceedings.sriweb.org

Curriculum. The term curriculum refers to the lessons and academic content taught in a school or in a specific course or program. Curriculum is often defined as the courses offered by a school, but it is rarely used in such a general sense in schools. Depending on how broadly educators define or employ the term, curriculum typically refers to the knowledge and skills students are expected to learn, which includes the learning standards or objectives they are expected to meet, the units and lessons that teachers teach, the assignments and projects given to students, the books, materials, videos, presentations, and readings used in a course, the tests, assessments, and other methods used to evaluate students' learning. An individual teacher's curriculum, for example, would be the specific learning standards, lessons, assignments, and materials used to organize and teach a particular course. Curriculum is often taken to mean a course of study. When imaginations are set free from the narrow notion that a course of study is a series of textbooks or specific outline of topics to be covered and objectives to be attained, broader and more meaningful notions emerge. A curriculum can become one's life course of action. It can mean the paths that have been followed and the paths intended to be followed. In this broad sense, curriculum can be viewed as a person's life experience (Connelly \& Clandinin, 1988).

Disabilities. Disabilities is an umbrella term, covering impairments, activity limitations, and participation restrictions (Simi, 1998).

Sensory-motor. Psychologist Jean Piaget proposed that humans experience four stages of cognitive or mental development starting from the day they are born all the way through adulthood. The first stage of their development is referred to as the sensory-motor stage. This stage begins at birth and lasts until 24 months of age. When a baby is born, it starts developing both physically and cognitively. Physical skills of a baby include crawling, grasping, pulling, as well as general physical growth. However, as a baby develops cognitive skills, it starts thinking about its behaviors and reacting to different stimuli such as noises, movement, and emotions (Piaget, 1958). 


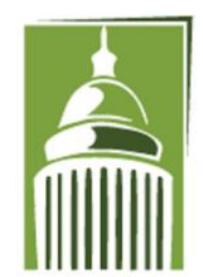

ARF

\section{Global Proceedings Repository \\ American Research Foundation}

ISSN 2476-017X

Available online at http://proceedings.sriweb.org

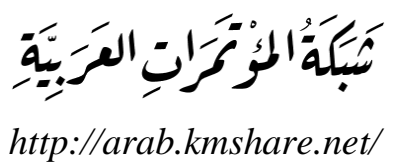

http://arab.kmshare.net/

\section{Literature Review}

A multitude of gifted and talented children and adolescents are sitting in their classroom with their abilities unrecognized, their needs unmet. Some are bored, patiently waiting for peers to learn skills and concepts that they had mastered one or two years earlier. Some find school intolerable, feigning illness or creating other excuses to avoid the trivia. Many develop poor study habits due to the slow pace of instruction and lack of challenge. Some feel pressured to hide their keen talents and skills from uninterested and unsympathetic peers. This chapter looks into the definitions of what gifted and talented means, their characteristics, ways to accommodate their educational needs - such as acceleration, enrichment, and differentiation -, and interventions targeting them.

How gifted students are defined, how they are educated, and how society receives them vary considerably across time and across different cultures. How these students are educated today depends on values and conceptualizations that may refer to previous generations. In order to understand the programs of the year, one must reflect on the values of yesteryear. Special educational programs for children with special needs have been wellaccepted by the American public, for example, as an essential part of the educational license of a free and appropriate education for all children since the 1960s. For a child with special learning problems, intellectual disabilities, or other disabilities, there is a complex system in special education that directs financial help to local school districts from both the state and federal government. Do gifted children fit under the definition of children with special needs? Why? In fact, should one be paying attention to a group of children who are already performing above the average in school? There is a touch of enlightened selfinterest in such support, since there is substantial evidence that many students will become the leaders of the future in medicine, law, sciences, business, arts, etc. It is in humanity's own family and societal interest to ensure a well-based, effective education for them (Terman \& Oden, 1959; Bloom, 1985).

During the 1950s, in New Zealand, the Department of Education required that gifted and talented students have their needs met through enrichment activities provided within regular classroom programs (Knudson, 2006). Gradually, there were more researches on gifted and talented children and the government began to focus on these students.

In 1997, the Ministry of Education in New Zealand launched its Advisory Group on Gifted Education. The role of this group was to advise the Ministry of Education on initiatives for gifted and talented students. The first gifted education policy was released in 2001. This policy consisted of nine principles. Only three out of them mentioned early childhood education (Ministry of Education, 2001). In August 2012, a revised gifted education policy was published by the Ministry of Education (Ministry of Education, 2012). Within 12 years in between the two policies, the Ministry of Education had 


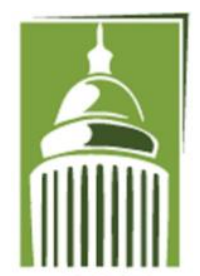

ARF

\section{Global Proceedings Repository \\ American Research Foundation}

ISSN 2476-017X

Available online at http://proceedings.sriweb.org

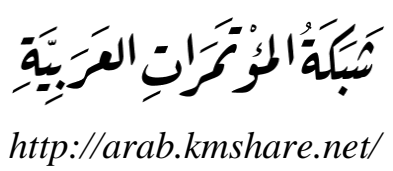

http://arab.kmshare.net/

instigated a number of initiatives (Wong \& Hansen, 2012). One of the remarkable achievements for initiatives was the introduction of the portal TeKeteIpurangi (TKI), which is a website developed to assist teachers and parents in supporting the learning process and development of gifted and talented students at all ages. Advisory and support groups were also formed to provide suggestions to the government on supporting these students. At the same time, research on gifted education had continued to grow, and universities now offer qualified majorities in gifted education. Overall, there has been significant improvement in gifted education in Aotearoa, New Zealand - except in early childhood settings (Wong \& Hansen, 2012).

Unfortunately, the needs of gifted children in early childhood education are still being overlooked (Wong \& Hansen, 2012). Yet, these younger gifted children share many of the same issues as gifted children in primary schools do. Gifted children in early childhood settings may also experience some additional challenges in their learning environment, and this has been largely ignored by society. Robinson (1977) has pointed out that it is not often what the gifted child does that is so remarkable, but rather when in the developmental process he or she does it. For example, the child who plays competitive chess at the age of five or six will naturally be seen as gifted, but is doing only what other children might do at the age of twelve or thirteen. The basic question of interest to the educator is: "can gifted children accomplish some mental tasks that other students cannot perform at all?" If the answer is "yes," then, the stimulation of such special abilities becomes a major responsibility to the educator.

Moreover, Rogers (1986), in a review of the existing literature, suggested that not only that gifted students are quantitatively different from the average student in their intellectual performance, but also that these quantitative differences may result in qualitatively different performances. For example, a student who masters calculus can achieve levels of problem-solving questions that are not available to students who have not mastered, or had the opportunity to master, calculus. There is a point, therefore, where quantitative differences seem to result in qualitatively different performances.

The specific study of giftedness and its nurture occurred in relatively modern times. Also, organized attempts to stimulate these abilities through education were developed even later.

In the United States (U.S.), Terman Longitudinal Study (Terman \& Oden, 1947; Terman \& Oden, 1959) has been particularly influential in putting an end to a series of myths about gifted students. Terman's sample of about 1400 students, studied throughout their life span, demonstrated that gifted children were not, as a group, physically weak, emotionally disturbed, or socially isolated, as had been previously suggested. Although the evidence of educational concern can be found in the establishment of special educational programs in 


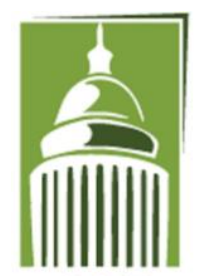

ARF

\section{Global Proceedings Repository \\ American Research Foundation}

ISSN 2476-017X

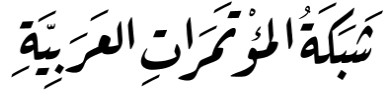

http://arab.kmshare.net/

Available online at http://proceedings.sriweb.org

St. Louis in the 1880s and Cleveland in the 1930s, the first widespread attention to the special needs of gifted students in public schools probably can be identified at beginning in the Sputnik era of the late 1950s (Tannenbaum,1983). The challenge provided by the Soviets to the United States' superiority in scientific fields stimulated to U.S. extensive curriculum reform through substantial investments by the National Science Foundation and, later, by the U.S. Office of Education (Good lad, 1964). Although such efforts were not exclusively directed toward gifted students, the emphasis of major themes in these curricula, and in providing actual practice in research, fits well into the educational needs of gifted students (Gallagher, 1985). The emphasis on the education of gifted students went into a sudden decrease from the mid 1960s to 1970s when public attention and the attention of educators shifted to issues of student equity. However, there was continued interest in the education of gifted students, largely due to the recognition of the need for a large and continuing supply of highly talented individuals to maintain U.S. leadership in business, industry, and higher education - among other disciplines - of the 21 st century (America 2000). Despite this attention, the attitude towards gifted students at a personal and societal level has often been ambivalent, in both the educational setting and in society at large.

Teachers may love the creative products of their mental processes but still feel the sting of envy when they observe some persons doing tasks and assessments - which are quite difficult for others to accomplish - with apparent ease. Such conflict between the public interest and personal feelings has been felt in many societies and has been a barrier to the education of gifted and talented students (Gallagher, 1984).

Finally, in order to identify the gifted and talented students, schools must first understand giftedness and talent. Some gifted students may not easily be identified because many factors mask the expression of giftedness. Below are mentioned the definition, identification, characteristics, and educating of the gifted and talented.

\section{Definitions of Gifted and Talented Students}

It is difficult to describe gifted education because it is compounded by problems of generality and definition. Giftedness itself has neither a tight definition nor a single agreement on its meaning. The definition is argued to be a flexible construct, and it has been a part of the debate over culture and policy for years (Gallager, 1994). In addition, it is difficult to agree on the definitions of intelligence, creativity and talent which are the components of giftedness; so it is expected not to agree on a definition of giftedness itself (Cramond, 2004). Thus, after more than 70 years of research in the field of gifted education, no agreement occurred on an operational definition of neither giftedness nor the most reliable method for identifying gifted students. Cramond (2004) argues that dissatisfaction with knowledge is the way that leads to further research, which means that agreeing on one definition to be true is to stop searching for the truth. He also argues that 


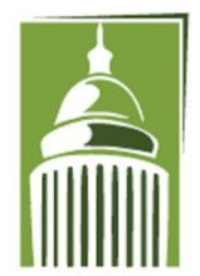

ARF

\section{Global Proceedings Repository \\ American Research Foundation}

ISSN 2476-017X

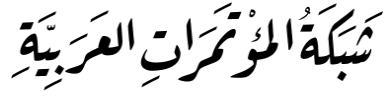

http://arab.kmshare.net/

Available online at http://proceedings.sriweb.org

such an agreement is unnecessary, as different cultural aspects are defined differently around the world, so why should giftedness be defined the same way across?

Therefore, since there is no one definition for "gifted" and "talented" as accepted by universities, the common use of the terms even by experts is vague and contradictory. Davis and Rimm (2004) as well as others use the single word "gifted" to refer to "gifted" and "talented". However, others see talent and giftedness as a continuum with giftedness at the upper end. As no accepted label distinguishes between these two visible groups, "extremely gifted" or "low incidence gifted" are used along with the "severely gifted", "profoundly gifted" or "exotically gifted" (Davis \& Rimm, 2004).

Some writers avoid the term gifted preferring to call them "able learners". For instance, Renzulli (2001) prefers the phrase "gifted behavior" which can be developed in some students at certain times and in certain circumstances. However, others argue that the term "gifted" should not be given to children as a result of the identification process so they prefer the phrase "potentially gifted" (Davis \& Rimm, 2004).

On the other hand, it is the concept of giftedness which is the basis of all assessment, curricular, and administrative decisions made about gifted individuals. The conceptualization of who is gifted determines how causing much discussion (such as grouping) is viewed. It is difficult to say if a single definition would result in positive progress in the field of educating gifted and talented students or lead to further arguments (Cramond, 2004). Davis \& Rimm (2004) state that when defining gifted and talented students, the definition must begin with the original definition by the U.S. Department of Education, or as it is also known as Marland's definition. This definition identified gifted and talented children as:

those who are professionally qualified persons who, due to outstanding abilities, are capable of high performance. These children required educational programs and services different from what is normally provided by the regular school program in order to realize their contribution to self and society (Marland, 1972) (p. 8).

In addition, many identificational strategies are based on the categories of this definition as it included children, who demonstrate achievements and/or potentials in general intellectual ability, specific academic achievement, creative or productive thinking, leadership ability, visual and performing arts, and psychomotor ability. Davis and Rimm (2004) believed that this definition is thoughtful and pleasing because it recognizes high general intelligence as well as gifts in specific academic areas and in the arts too. Moreover, it brings attention to creativity, leadership and psychomotor gifts and talents. Furthermore, this definition indicates that gifted and talented students require differentiation in education and services which justifies the development of gifted programs. It also recognizes the two fundamental objectives of gifted programs; helping 


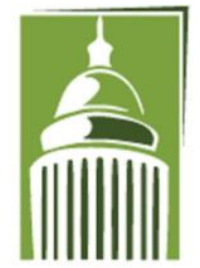

A R F

\section{Global Proceedings Repository \\ American Research Foundation}

ISSN 2476-017X

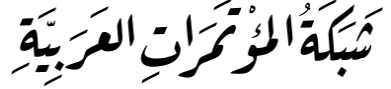

http://arab.kmshare.net/

Available online at http://proceedings.sriweb.org

individuals get out of their high potential, and providing society with educated professionals who are creative as leaders and problem solvers. In addition, it includes underachieving students by taking high performance achievement and/or potential ability into consideration (Davis \& Rimm, 2004).

Renzulli's Three-Ring Model (shown below in figure 2) is another famous theory on giftedness. Renzulli (2003) suggested that gifted behavior reflects an interaction among three basic groups of human qualities. These groups include the general and/or specific ability of being above average, but not necessarily high, high levels of task commitment (motivation), and high levels of creativity. He identifies gifted students as those possessing or capable of developing this compound set of qualities and applying them to any potential valuable area of human performance (Renzulli, 2001).

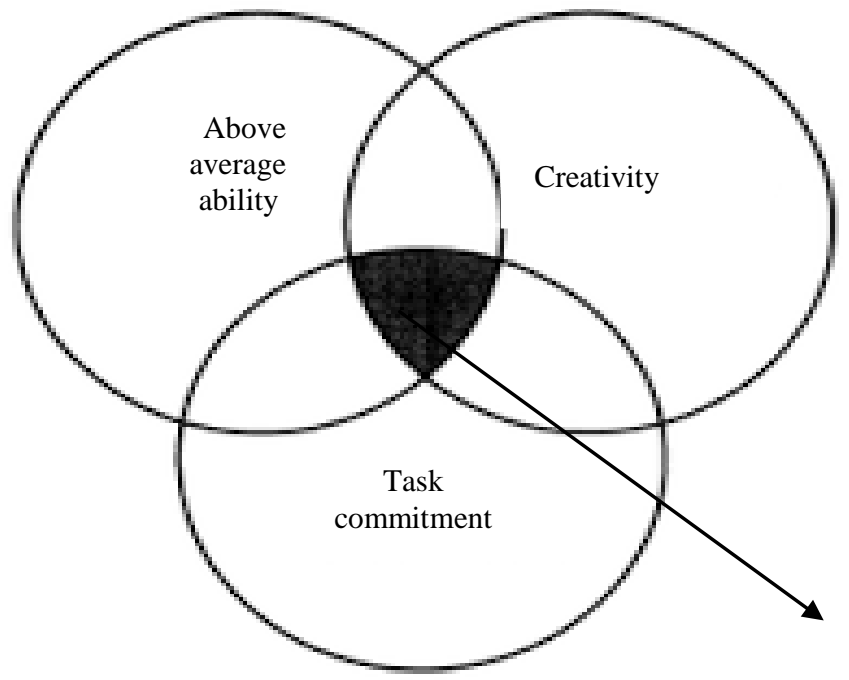

Giftedness and Talent

\section{Figure 2: Renzulli’s (2003) Three-Ring Model}

Gagné introduced another theory about giftedness and talent which is known as the Differentiated Model of Giftedness and Talent (Gagné, 2000). This model introduces a specific distinction between gifts and talents as it indicates that gifts, representing general natural abilities to do something, are "untaught natural abilities"; while talents, representing specific skills, are "learned capabilities". He also introduces four types of inborn gifts which include intellectual (such as reasoning and judgment), creative (such as 


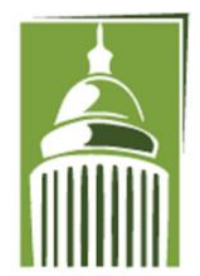

ARF

\section{Global Proceedings Repository \\ American Research Foundation}

ISSN 2476-017X

Available online at http://proceedings.sriweb.org

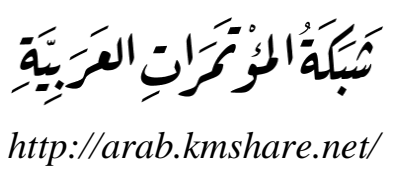

http://arab.kmshare.net/

inventiveness and managing nation), socio-affective (such as perceptiveness, sharing feelings and ability of being tactful), and sensory-motor (such as auditory and coordination). Gagné also identifies seven categories of talents that include academics, arts, business, leisure, social action, sports and technology. Gagné further indicates that there are some personal factors that influence talent development. These factors are as follows: physical characteristics, motivation such as needs and values, volition such as will-power and effort, self management such as work habits, and personality. There are also environmental influences which include one's surrounding or background (such as physical and cultural), persons (such as teachers, parents and peers), provisions (such as services and activities), and events (such as encounters and awards). He states that the development of talent is also affected by chance factors, such as one's family environment, a school gifted program, or a bad accident (Davis \& Rimm, 2004).

\section{Identification of Gifted and Talented Students}

Coleman (2003) summarizes that the best identification methods to find students with gifts and talents depending on multiple criteria should involve the following:

- Multiple types of information: such as indicators of student's cognitive abilities, academic achievement, and performance in various settings, interests, creativity, motivation, and learning characteristics/behaviors,

- Various sources of information: such as test scores, school grades, people's comments involved in students' education (parents, teachers, counselors or peers) in addition to the students themselves,

- Different time lengths: to make sure that those students are not missed by one procedure of identification only.

It is important to make sure that standardized measures use appropriate normative samples with the students who are tested taking into consideration any factor that may affect the identification such as nationality, language or the presence of a disability (Coleman, 2003).

The first comprehensive psycho educational assessment tool designed for students with special needs in Lebanon and the Arab World is the Battery of Developmental Assessment (BDA) (Husseini Bibi, 2005). It consists of culture-fair tests, subtests and hands-on activities that help teachers and counselors identify students who are at risk of scholastic delay, and those who perform above average. The premise upon which the BDA is based is the perpetual integration of assessment, with counseling and instruction. The BDA provides teachers with guidelines and strategies that are necessary to help them overcome their various academic and /or behavioral problems. 


\section{Global Proceedings Repository \\ American Research Foundation}

ISSN 2476-017X

Available online at http://proceedings.sriweb.org

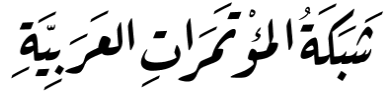

http://arab.kmshare.net/

A R F

\section{Characteristics of Gifted and Talented Students}

Gifted children are different from normal children in many ways. They have unique and different characteristics than their peers which means that they have unique and different needs as well. Although gifted children share similar characteristics, they differ from one another as each child has his or her unique characteristics, interests, learning styles, energy levels and needs as well as other aspects such as personalities, habits, mental health and motivation (Davis \& Rimm, 2004). Parents, teachers and educators need to recognize these characteristics, so that they can support and motivate them. The characteristics of gifted children are discussed more in the table below.

\begin{tabular}{|l|l|}
\hline Intellectual Traits & Personality Traits \\
\hline Exceptional reasoning ability & Insightful \\
Intellectual curiosity & Need to understand \\
Rapid learning rate & Need for mental stimulation \\
Facility for abstraction & Perfectionism \\
Complex thought processes & Need for precision /logic \\
Vivid imagination & Excellent sense of humor \\
Early moral concern & Sensitivity /empathy \\
Passion for learning & Intensity \\
Powers for concentration & Perseverance \\
Analytical thinking & Acute self-awareness \\
Divergent thinking /creativity & Nonconformity \\
Keen sense of justice & Questioning to rules / authority \\
Capacity for reflection & Tendency to introversion \\
\hline
\end{tabular}

\section{Table 1: Gifted Traits}

\section{Educating Gifted and Talented Students}

Students who are gifted and talented receive their education in a variety of settings. No data is available to indicate the amount of time they spend in a particular setting, and decisions about placement often depend on the breadth and level of a student's abilities as well as on the program options generally available based on local and state policies (Friend, 2008). 


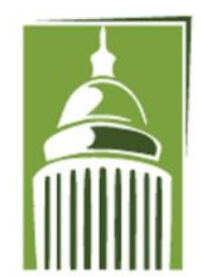

AR F

\section{Global Proceedings Repository \\ American Research Foundation}

ISSN 2476-017X

Available online at http://proceedings.sriweb.org

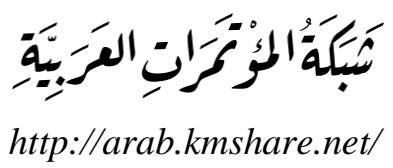

http://arab.kmshare.net/

\section{Differentiating curriculum: acceleration and enrichment.}

Differentiation. Differentiation for students who are gifted, as for all students, refers to an instructional approach that assumes that students need many different avenues to reach their learning potential (Tomlinson, 2001). It can address the content students learn, the assessment tools through which learning is measured, the tasks students complete, and the instructional strategies employed.

Curriculum design is one major component of differentiation for gifted students (Maker \& Schiever, 2005). Related to curriculum design is materials' selection. In classrooms, to serve these students, materials should go beyond a single textbook and should further include advanced readings that present interesting and challenging ideas, treat knowledge as tentative and open ended, and provide a conceptual depth that allows students to make interdisciplinary connections (Friend, 2008).

Acceleration. Acceleration or advancing learners through levels of curriculum and programs according to individual achievement and performance, assumes that different students of the same age are at different levels of learning within and across learning areas. Acceleration occurs in many ways. As for some students, it means allowing them to begin school before the age established through district/country policies; while for other students, it might mean moving through two grade levels in a single year, skipping a grade level altogether, or entering high school or even college before the age typically permitted (Friend, 2008).

Another type of acceleration is content based; some students may need to advance quickly in Mathematics or English but not in other subject areas. This practice, referred to as curriculum flexibility, makes learning options responsive to the learners' needs and contextual demands by offering content-based acceleration practices at all levels of schooling and in all subject areas. For learners, who are gifted with precocious abilities in the verbal, scientific and artistic areas, such flexibility is crucial (Friend, 2008; Heward, 2006; Turnbull \& Wehmeyer, 2007). Another high school option is dual enrollment courses in which students take courses at local community colleges or universities, or arrangements are made for those courses to be offered on the high school campus. Students earn college credit that then counts towards an undergraduate degree (Friend, 2008). One additional acceleration option found primarily in high school is the use of telecommunications. Advanced courses are made available through interactive video or similar mechanisms. Technology can offer options for independent study with university faculty and research project work conducted globally.

Enrichment. Another instructional approach to meet the needs of students who are gifted and talented is enrichment, the extension of regular curriculum with different examples and associations that build complex ideas (Freeman, 2000). 


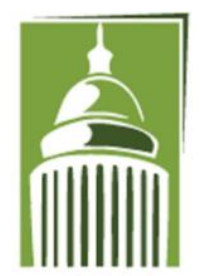

AR F

\section{Global Proceedings Repository \\ American Research Foundation}

ISSN 2476-017X

Available online at http://proceedings.sriweb.org

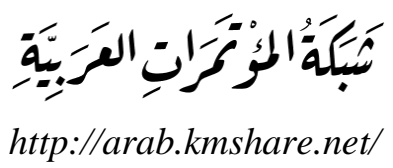

http://arab.kmshare.net/

Enrichment can encourage students' creativity and the development of criticalthinking skills. It can also be an appropriate substitute for materials that are too basic for some students' skill levels. Of course, if enrichment is practiced only for students who are considered gifted and not as a part of class wide differentiation, it can lead to the students' isolation and the feeling of being different.

\section{Lesson differentiation in the regular classroom.}

Curriculum compacting. Some students who are gifted and talented are often already familiar with the concepts being taught in their classrooms. If these students' needs are not addressed, they can become frustrated (Friend, 2008). A solution to this problem is curriculum compacting, in which the goals of an instructional unit are identified, students' mastery of all or part of the goals is documented, and alternative instruction is provided as appropriate (Renzulli, 2003). Curriculum compacting involves compressing the instructional content and materials so that academically-able students have more time to work on more challenging materials (Heward, 2006). Compacting often makes it possible for students to complete a single semester. A study showed that when teachers compact the curriculum, gifted and talented students score significantly higher on tests of mathematical and scientific concepts after the content was changed. For curriculum compacting to be effective, teachers must have a substantial understanding of the curricular content and not only condense the material but also modify its presentation, create more meaningful instruction, and evaluate that instruction for individual students (Heward, 2006).

Tiered lessons. A tiered lesson provides different extensions of the same basic lesson for groups of students of differing abilities (Heward, 2006). For example, after the whole class is exposed to a basic lesson on a poem, three groups of students might work on follow-up activities or assignments of basic, middle, and high difficulty.

Curriculum adaptations. Two other strategies that provide curriculum adaptations or augmentations involve the use of curriculum extension techniques and the application of cognitive taxonomies to the design of activity, lesson, and unit plans. Curriculum extension refers to the efforts to expand the breadth of the coverage of a given topic. Students who are gifted and talented learn content quicker than the peers do; they do not need as much repetition. As such, their curriculum extension activities should not simply repeat the same task but should challenge them at a higher level (Tumbull \& Wehmeyer, 2007).

Teachers can take their students to a higher level by using cognitive taxonomies. Taxonomy is an ordered list or classification of something. Cognitive taxonomies are ordered lists of cognitive skills or activities that can be used to differentiate expectations for students. The most familiar taxonomy is the one developed by Bloom which categorizes the cognitive skills that students use when achieving their learning goals. As a student 


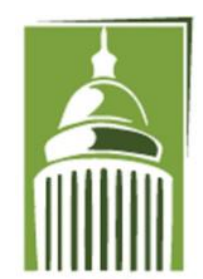

A R F

\section{Global Proceedings Repository \\ American Research Foundation}

ISSN 2476-017X

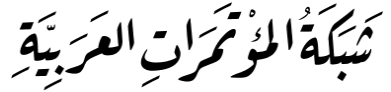

http://arab.kmshare.net/

Available online at http://proceedings.sriweb.org

ascends Bloom's taxonomy, he or she faces increasingly cognitive demands (Heward, 2006; Tumbull \& Wehmeyer, 2007).

Teachers can differentiate what they expect from students by designing lesson and activity objectives that range from less to more complex levels of interaction with materials. They also can extend the curriculum for gifted students by having their students engage in activities that move up the taxonomy, from applying information and knowledge to solving novel problems, to synthesizing information, and to creating new patterns or structures. These activities will teach students the skills they need to be more creative and to develop effective thinking skills.

\section{Curriculum differentiation outside the classroom.}

Training and practice. For some students with excellent talents, the activities that take place outside the classroom may be more important and rewarding than those within it. The teachers should always attempt to connect class work with human and physical resources available in the community (Heward, 2006). These activities include training and tutoring programs. These opportunities allow students with exceptional talents to be exposed to one of the most powerful and proven educational strategies-modeling, practice, direct feedback and reinforcement of important behaviors-within a real-world setting. A good tutor provides students with exceptional talents opportunities to develop their conceptual and performance skills in a real-world setting (Heward, 2006).

Special courses workshops. They may be offered in many communities, arts and cultural venues, museums, and recreation centers. These courses which may or may not award high school or college continuing education credits, form a rich variety of opportunities for students to encounter tutors, new friends, and wide concepts that may not be available in the restrictions of the school curriculum.

Junior Great books.This is a highly structured educational program in the U.S. in which students read selections from a number of areas, including classics, philosophy, fiction, and poetry, and then discuss their meaning with teachers (Heward, 2006).

Summer programs. Many summer programs are available to gifted and talented students that offer educational experiences as diverse as environmental studies. Summer programs are usually relatively brief but intense in learning experiences which concentrate on specific areas of intellectual, artistic, or cultural affairs (Friend, 2008).

International experiences. Numerous international programs offer academic credits for study at participating educational agencies around the world (Heward, 2006). They are excellent opportunities for students to develop global international skills with academically strict studies. 


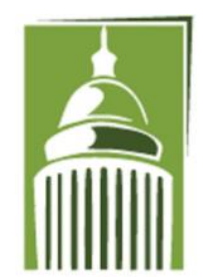

AR F

\section{Global Proceedings Repository \\ American Research Foundation}

ISSN 2476-017X

Available online at http://proceedings.sriweb.org

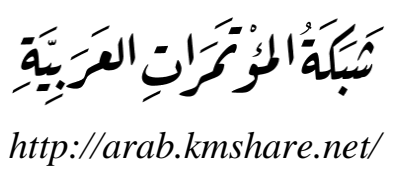

http://arab.kmshare.net/

\section{Instructional models and methods.}

The School Wide enrichment model. Renzulli and colleagues developed and accomplished an enrichment model known as the school wide enrichment model (Renzulli, 2003). Its major goal is to promote challenging and high-end learning across a range of school types, levels, and demographic differences by creating services that can be integrated across the general education curriculum to assist all students, not just those who are gifted. This model considers schools as the places for talents development and provide opportunities which are challenging and enjoyable to the gifted. There are three types of enrichment approaches under the model. Type (1) enrichment exposes the students to a wide variety of topics, disciplines, occupations, hobbies, persons, places, and events that ordinarily would not be included in the general education curriculum. For example, Type (1) experiences may involve community speakers, demonstrations, performances, multimedia presentations, or other illustrative formats. Type (2) enrichment focuses on resources that promote creative thinking, problem solving, and critical-thinking skills. This kind of enrichment consists of how-to-learn skills, including written, oral, and visual communication skills. Other Type (2) skills are specific to a particular student's talents and interests. When a student becomes interested in following a self-selected area of interest and commits the time necessary for this endeavor, Type (3) enrichment occurs. It consists of advanced level studies with greater depth and complexity.

Maker's Active Problem Solver model. It proposes a process by which the key elements of content, process, products, and the environment of a child's learning situation can be modified (Maker \& Schiever, 2005).

Problem Based Learning model. Problem-based learning (PBL) challenges students to "learn to learn" while working cooperatively in groups to seek solutions to real - world problems. The problems are used to engage students' curiosity and initiate learning of subject matter (Heward, 2006). The students explore the problem, gather research data about it, and design interventions to solve it. The instructional techniques needed by the teacher include high-level questioning skills, listening skills, conferencing skills, and tutoring in order to guide the process (Friend, 2008). PBL also includes flexible team grouping and whole-class discussion. Problem resolution usually involves student-initiated projects and presentations, guided by the teacher.

\section{Ability grouping.}

Ability and performance group. Strong research evidence supports the effectiveness of ability grouping for gifted students in accelerated classes, enrichment programs, advanced placement programs and others (Heward, 2006). 


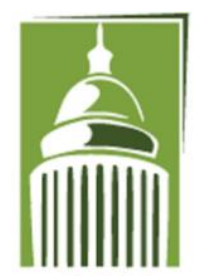

AR F

\section{Global Proceedings Repository \\ American Research Foundation}

ISSN 2476-017X

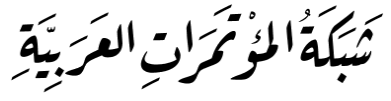

http://arab.kmshare.net/

Available online at http://proceedings.sriweb.org

Ability and performance grouping has been used extensively in programs for musically and artistically gifted students, and for athletically talented students with little argument. Grouping allows for more appropriate, rapid, and advanced instruction, which matches the rapidly developing skills and capabilities of gifted students (Friend, 2008).

$X Y Z$ grouping or tracking. XYZ grouping places students into different levels of curriculum requirements or offerings according to high, middle, and low ability based on test scores or other indicators or related to prediction of performance (Heward, 2006).

Within-class grouping. Within-class grouping is part of the concept of universal design for learning (UDL), and it can be effective at all levels of schooling and for students with many types of special needs. Students within the same heterogeneous class are grouped for instruction according to their achievement. The most common form of within-class grouping is regrouping by subject, where students are generally grouped into three or more levels, and they study materials from different textbooks at different levels (Friend, 2008; Heward, 2006).

Cluster grouping. In cluster grouping, several talented students receive specialized instruction from a teacher who treats them as talented. Four to six talented students should make up a group of talented students with close abilities. Cluster grouping can be used effectively at all grade levels and in all subject areas. It can be especially effective when there are not enough students to form an advanced placement section for a particular subject. Cluster grouping is also a welcome option in rural settings or wherever small numbers of gifted students make appropriate accommodations difficult (Heward, 2006). Cross-Grade grouping. Cross-grade grouping was first tried in the Joplin Plan in Missouri in the 1950s. In this model, students in the fourth, fifth, and sixth grades were broken into nine reading groups, ranging from the second-grade to ninth-grade levels. Students went to reading class at the same hour but to the level of instruction at which they were achieving (Heward, 2006). Other types of cross grade grouping are ability-grouped class assignment, ability grouping for selected subjects, non-graded plans, and special class. Cross-grade grouping is an effective means of delivering differentiated instruction, and the gain has been found similar to those of within-grade grouping achievement. Other types of grouping are peer tutoring pairs, cooperative grouping for like-ability students, and mixed-ability cooperative grouping. 


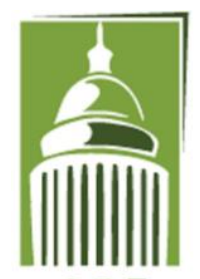

AR F

\section{Global Proceedings Repository \\ American Research Foundation}

ISSN 2476-017X

Available online at http://proceedings.sriweb.org

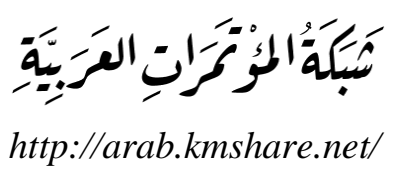

http://arab.kmshare.net/

Specific interventions for diverse populations. General interventions that have been documented as successful with learners identified as gifted and economically disadvantaged include early attention to needs, family involvement, use of effective instructional and leadership strategies in the school, experiential learning approaches, encouragement of self-expression, community involvement, counseling efforts, and building on strengths.

In summary, giftedness and talent have broad meaning and several definitions. However, researchers agree that these students are highly able and their abilities are related to cognitive, physical, or emotional areas. These abilities lead to the categorization of the characteristics of gifted and talented students, and help in identifying them. After identification, the researchers emphasize the importance of an educational program or plan to enhance students' performance and allow them to grow and live up to their potentials. This plan would include the differentiation of the curriculum inside classroom such as, acceleration, enrichment, curriculum compacting and tiered lessons, or differentiation outside the classroom such as, training and practicing or summer programs.

\section{Methodology}

This chapter provides an overview of the methodology, presents the sample of participants in the study, and describes the model used. The study was conducted at Safir High School in Ghazeye and at Generations High School in Nabatieh. The study adopted a mixed method approach that involves collecting, analyzing, and integrating quantitative and qualitative data. The main research instruments were questionnaires, interview schedules and BDA test for students nominated by their schools as gifted and talented. Excel was used to quantitatively analyze the questionnaire data.

\section{Likert Questionnaire: Closed Ended Questions}

A series of questions were used to collect information from teachers, where they responded in the form of Likert-type statements, each with five choices of response, ranging from "strongly agree" to "strongly disagree", to study their awareness of the program model for the gifted and talented students alike (Appendix 1).

\section{Structured Interview}

A structured interview (Appendix 2) was done with Safir and Generations High School principals. The following questions were proposed to study if these schools meet the gifted and talented students' needs.

- $\quad$ Do gifted children need a special program?

- $\quad$ Did you adopt or choose to have gifted and talented programs in your school?

- How does it affect the students' performance? 


\section{Global Proceedings Repository \\ American Research Foundation}

ISSN 2476-017X

Available online at http://proceedings.sriweb.org

AR F

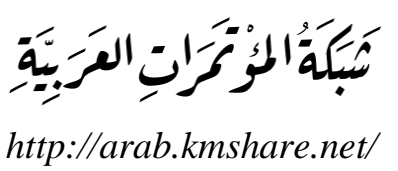

http://arab.kmshare.net/

- What problems are you facing while applying the program?

- Can we adopt a program from another cultures or country and apply it in Lebanon?

- $\quad$ Do you have well trained teachers to work with this program or a wellprogrammed team to work?

\section{An Awareness Presentation About:}

- Who are the gifted and talented students?

- What are the needs of the gifted and talented students?

- Where are they? And how can we identify them?

- What is the importance of addressing the needs of the gifted and talented students?

- $\quad$ How can education help and support the gifted and talented students?

\section{Battery of Developmental Assessment (BDA) for the Nominated Students}

A recording nomination teacher and parent cards (Appendix 3) was directed to school principals to nominate their gifted and talented students. The students were subjected to BDA test, a clinical assessment tool. It encompasses the use of varied procedures and multiple activities to evaluate and record developmental and psychological characteristics of students.

It is the first comprehensive psycho-educational assessment tool designed for students with special needs in Lebanon (Husseini Bibi, 2005). The BDAhas been developed to meet the norms of the Lebanese student population. Since the number of students with special needs is increasing, the BDA consists of tests, subtests, and checklists, that:

- Identify the abilities of students,

- Discover their various needs,

- $\quad$ Design Individual Educational Plans (IEPs) for appropriate intervention.

\section{Results and Discussion}

Gifted students are students who are above average competence in human ability, and talent as above-average performance in particular field. They are professionally qualified persons, who due to outstanding abilities are capable of high performance. Teachers identify them only through their grades, defining them as high achieving students; although they could be gifted and talented underachievers. Several factors affect negatively or positively the student's giftedness and talent where Gagné called them catalysts. They could be physical characteristics, motivation such as needs and values, volition such as will-power and effort, self management such as work habits, and personality traits. These factors could stop the giftedness and talent progress while teachers 
and the Lebanese society are neglecting their needs because they are high achievers and they usually get high scores on assessment. These children require educational programs and services different from what is normally provided by the regular school programs in order to realize their contribution to society.

\section{A. Data Analysis, Results and Discussion for the survey research and BDA test.}

\section{Demographic Characteristics}

In this case 85 respondents were counted, 79 of who were females while the remaining 6 respondents were males (see Figure 3 below).

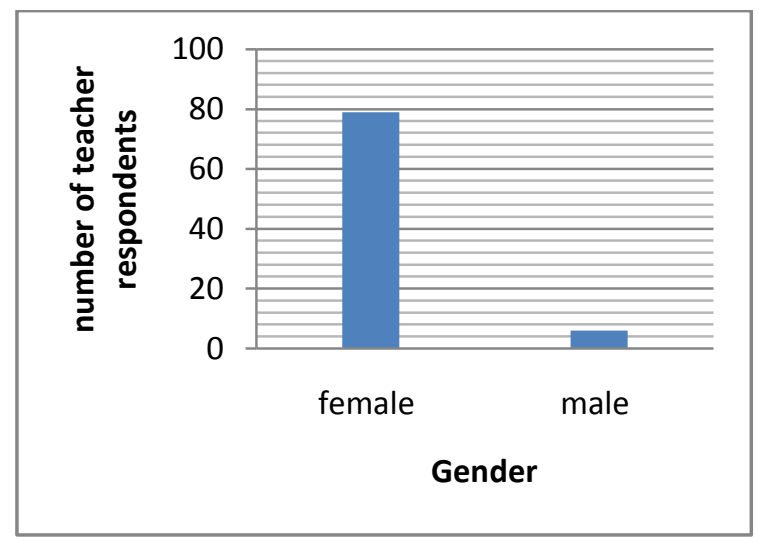

Figure 3: Gender of respondents

Forty three of the responding teachers had a Master's degree in subject matter, 40 had a Bachelor and the last two respondents, one had TD (Teaching Diploma) and the other had a Master's degree in educational management (see Figure 4 below). 


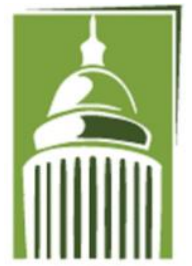

A R F
Global Proceedings Repository

American Research Foundation

ISSN 2476-017X

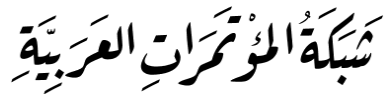

http://arab.kmshare.net/

Available online at http://proceedings.sriweb.org

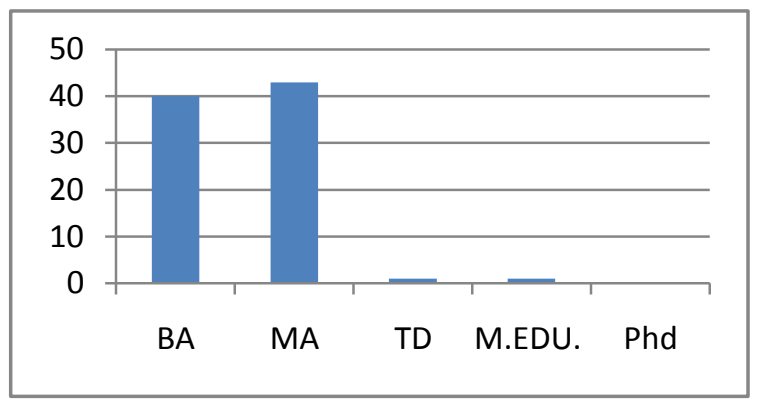

Figure 4: Educational Level

\section{Programs for the Gifted and Talented}

The study sought to examine if teachers believed whether programs for the gifted and talented students were actually in existence in their respective school or not, to explore what those programs were. Majority of the respondents $(47 \%)$ strongly disagree that their respective schools do have any programs for gifted and talented children (see Figure 5 below).

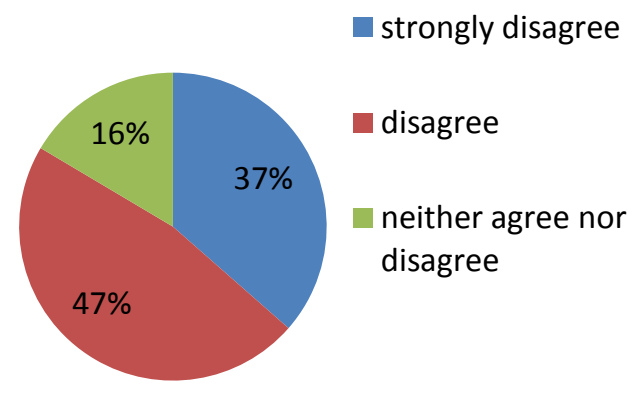

\section{Figure 5: Existence of gifted programs in schools}

Figure 5, above, shows that $16 \%$ of the respondents are neutral due to the unawareness of the meaning or types of gifted and talented students programs. However, as shown in figure 6 , below, $51 \%$ of the teachers support the concept that gifted and talented students require a differentiated curriculum. 


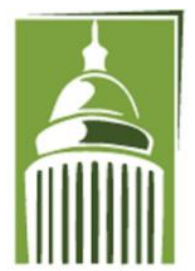

AR F

\section{Global Proceedings Repository \\ American Research Foundation}

ISSN 2476-017X

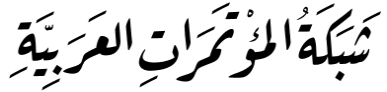

http://arab.kmshare.net/

Available online at http://proceedings.sriweb.org

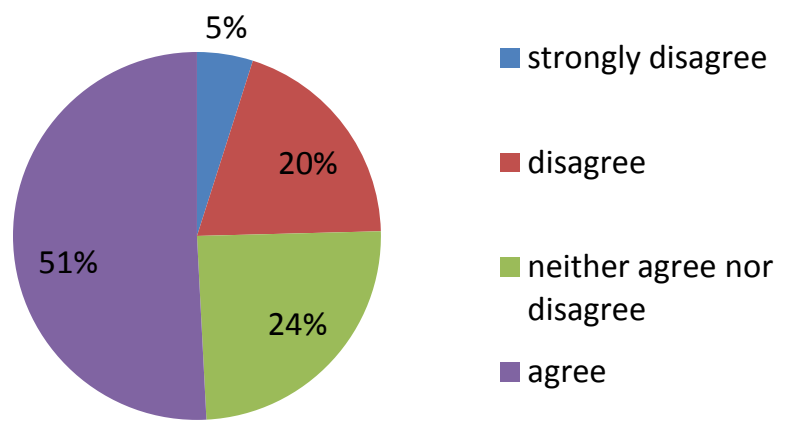

Figure 6: Gifted and talented students require a differentiated curriculum

\section{Opinions of Teachers on Learners who are Gifted and Talented}

Respondents also gave various opinions about the attributes of the gifted and talented learners in relation to the current curriculum in place. Table 1 below shows that out of 85 respondents, 64 (75\%) agreed that gifted children were disruptive with $15(18 \%)$ disagreeing and $6(7 \%)$ were neutral on this. Majority of the respondents $61(72 \%)$ agreed that work which was too easy frustrated gifted children while $16(32 \%)$ disagreed. On the curriculum, 28 (33\%) of the respondents felt that the current curriculum was suitable for all learners including those gifted and talented while $45(53 \%)$ felt it was unsuitable and 12 (14\%) were neutral. Majority of the respondents, $55(64 \%)$ were of the opinion that a differentiated curriculum should be established for gifted and talented learners and 15 (18\%) did not feel that it was necessary to have such a curriculum.

\begin{tabular}{|l|l|l|l|l|l|}
\hline & $\begin{array}{l}\text { Strongly } \\
\text { disagree }\end{array}$ & Disagree & Neutral & Agree & $\begin{array}{l}\text { Strongly } \\
\text { agree }\end{array}$ \\
\hline $\begin{array}{l}\text { Teachers often see gifted children as } \\
\text { annoying students. }\end{array}$ & $7 \%$ & $11 \%$ & $7 \%$ & $54 \%$ & $21 \%$ \\
\hline $\begin{array}{l}\text { Work that is too easy frustrates gifted } \\
\text { children. }\end{array}$ & $20 \%$ & $12 \%$ & $9 \%$ & $52 \%$ & $20 \%$ \\
\hline
\end{tabular}




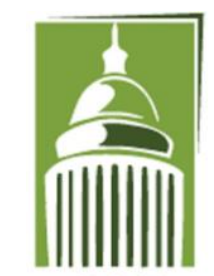

AR F

\section{Global Proceedings Repository \\ American Research Foundation}

ISSN 2476-017X

Available online at http://proceedings.sriweb.org

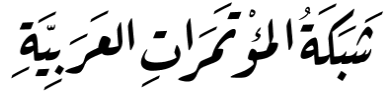

http://arab.kmshare.net/

\begin{tabular}{|l|l|l|l|l|l|}
\hline $\begin{array}{l}\text { If not challenged, gifted children's } \\
\text { ability will be weakened. }\end{array}$ & $19 \%$ & $19 \%$ & $16 \%$ & $46 \%$ & $19 \%$ \\
\hline Not all gifted children show creativity. & $7 \%$ & $23 \%$ & $14 \%$ & $42 \%$ & $14 \%$ \\
\hline Not all gifted children show leadership. & $7 \%$ & $23 \%$ & $14 \%$ & $42 \%$ & $14 \%$ \\
\hline $\begin{array}{l}\text { Not all gifted children show physical } \\
\text { expertise. }\end{array}$ & $7 \%$ & $23 \%$ & $14 \%$ & $42 \%$ & $14 \%$ \\
\hline $\begin{array}{l}\text { The regular curriculum in use is not } \\
\text { suitable for all learners including those } \\
\text { gifted and talented students. }\end{array}$ & $7 \%$ & $26 \%$ & $14 \%$ & $42 \%$ & $11 \%$ \\
\hline $\begin{array}{l}\text { There is a program for the gifted and } \\
\text { talented students in my school. }\end{array}$ & $37 \%$ & $47 \%$ & $16 \%$ & $0 \%$ & $0 \%$ \\
\hline $\begin{array}{l}\text { Gifted and talented students require a } \\
\text { differentiated curriculum. }\end{array}$ & $4 \%$ & $14 \%$ & $18 \%$ & $28 \%$ & $36 \%$ \\
\hline $\begin{array}{l}\text { Teachers describe gifted and talented } \\
\text { students as high achievers. }\end{array}$ & $0 \%$ & $25 \%$ & $11 \%$ & $35 \%$ & $29 \%$ \\
\hline
\end{tabular}

Table 1: Teachers` opinions on gifted and talented learners

Learners who are gifted and talented become problematic to their parents, educators and society as a whole when they are not understood for what they are. Ladson-Billings (1995) claims that responsive teachers place learners at the centre of teaching and learning. They feel obligated and responsible for the students' cognitive, academic, and effective well-being and they employ teaching methods especially those established towards improving the intellectual, social, emotional, political, and cultural growth on their students. This means that teachers need to be competent enough to come up with strategies of handling gifted and talented learners. Otherwise, they may be seen as problematic, and hence, their talents may be underdeveloped and underutilized.

The analysis of Table 1 above shows that due to the fact that all teachers and principals view gifted and talented student as annoying students, and that the curriculum is not suitable for the gifted students, there are still no programs to take care of and satisfy the needs of these students. Intervention for further talent exploration and the inclusion of a dynamic and supportive teacher is a persistent need. 


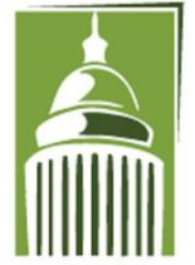

ARF

\section{Global Proceedings Repository \\ American Research Foundation}

ISSN 2476-017X

Available online at http://proceedings.sriweb.org

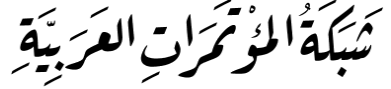

http://arab.kmshare.net/

\section{BDA result}

Among the 55 nominated students, only one student was identified as gifted students (see Figure 7 below and Appendix 4).

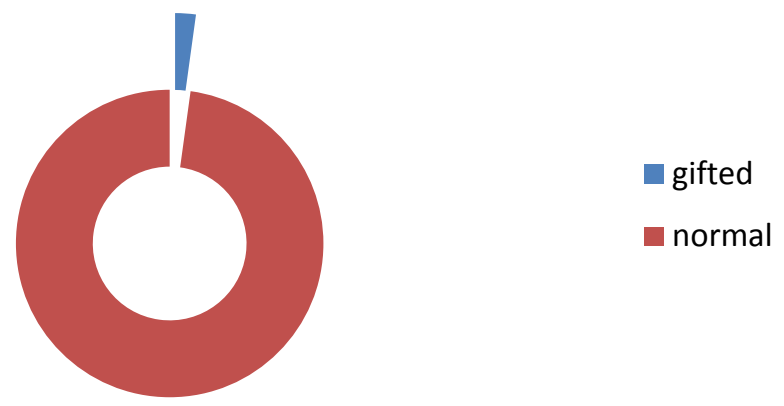

Figure 7: Nominated students

\section{B. Seminar}

After analyzing the survey and finding that the vast majority of teachers define gifted and talented students incorrectly, Safir High school and Generations High school were invited to a seminar titled "Gifted and talented students are neglected and we are all responsible". The seminar was done at the Lebanese International University (LIU) in Saida in collaboration with the Arab Council for the Gifted and Talented (ACGT). The seminar discussed the following aspects:

- Who are the gifted and talented students?

- What are the needs of the gifted and talented?

- $\quad$ Where are they? And how can we identify them?

- What is the importance of addressing the needs of the gifted and talented?

- $\quad$ How can education help and support the gifted and talented?

The seminar was be a good start for analyzing correctly the students' behavior and categorizing them appropriately.

\section{Conclusion}

Teachers are considered the corner stone in any sound educational building. The achievement of educational goals depends on them. It is the teachers' great responsibility to direct students, develop their talents, build up their personalities, to counter the destructive and the suspicious principles, in addition to countless other responsibilities. Yet, taking 


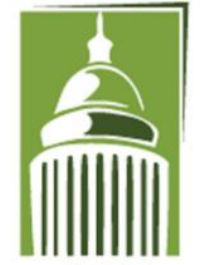

A R F

\section{Global Proceedings Repository \\ American Research Foundation}

ISSN 2476-017X

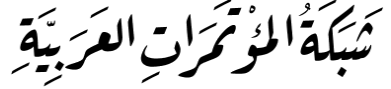

http://arab.kmshare.net/

Available online at http://proceedings.sriweb.org

care of the talented should be a priority. Teachers should be trained on how to deal with gifted students, how to implement a program model which will limit students' problems, increase students' performance, and allow gifted and talented students to grow their abilities normally. The following are proposed steps for Lebanese gifted and talented students as table 2 below shows:

\section{Training Teachers on identifying gifted students}

\section{Program model design to be compatible with each student's need}

Table 2: Steps for Lebanon in gifted education

\section{Training Teachers on Identifying Gifted Students}

One key way classroom teachers can broaden understanding of gifted students is through knowledge of the general characteristics that intellectually gifted children exhibit. Characteristics in the cognitive and affective domains most commonly appear in general classroom behavior and, therefore, may be observed by the classroom teacher. Recognizing these general traits and understanding how they may reveal themselves in the classroom is an important step toward working effectively with this unique group of children and some of these behaviors are listed and described below in Table 3. Positive traits are included along with those behaviors that may frustrate teachers. If a student in the classroom exhibits these characteristics on a consistent basis, there is a good chance he or she is gifted. 


\section{Global Proceedings Repository \\ American Research Foundation}

ISSN 2476-017X

Available online at http://proceedings.sriweb.org

\begin{tabular}{|l|l|}
\hline Intellectual Traits & Personality Traits \\
\hline Exceptional reasoning ability & Insightful \\
Intellectual curiosity & Need to understand \\
Rapid learning rate & Need for mental stimulation \\
Facility for abstraction & Perfectionism \\
Complex thought processes & Need for precision /logic \\
Vivid imagination & Excellent sense of humor \\
Early moral concern & Sensitivity /empathy \\
Passion for learning & Intensity \\
Powers for concentration & Perseverance \\
Analytical thinking & Acute self-awareness \\
Divergent thinking /creativity & Nonconformity \\
Keen sense of justice & Questioning to rules / authority \\
Capacity for reflection & Tendency to introversion \\
& \\
\hline
\end{tabular}

Table 3: Traits of gifted and talented students

After identifying students as gifted or not, they should respond to a specific test to identify their needs. The result of the test will detect which program model fits with the student's needs and his interest. Battery of developmental assessment (BDA) test assesses students' intelligence, creative thinking abilities, readiness and special abilities, objectivity achievement, and student personality (Husseini Bibi, 2005). 


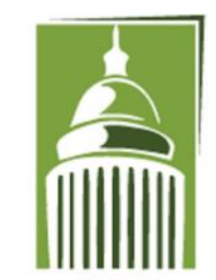

ARF

\section{Global Proceedings Repository \\ American Research Foundation}

ISSN 2476-017X

Available online at http://proceedings.sriweb.org

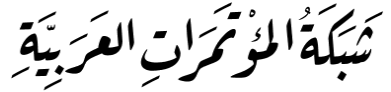

http://arab.kmshare.net/

\section{Program Model}

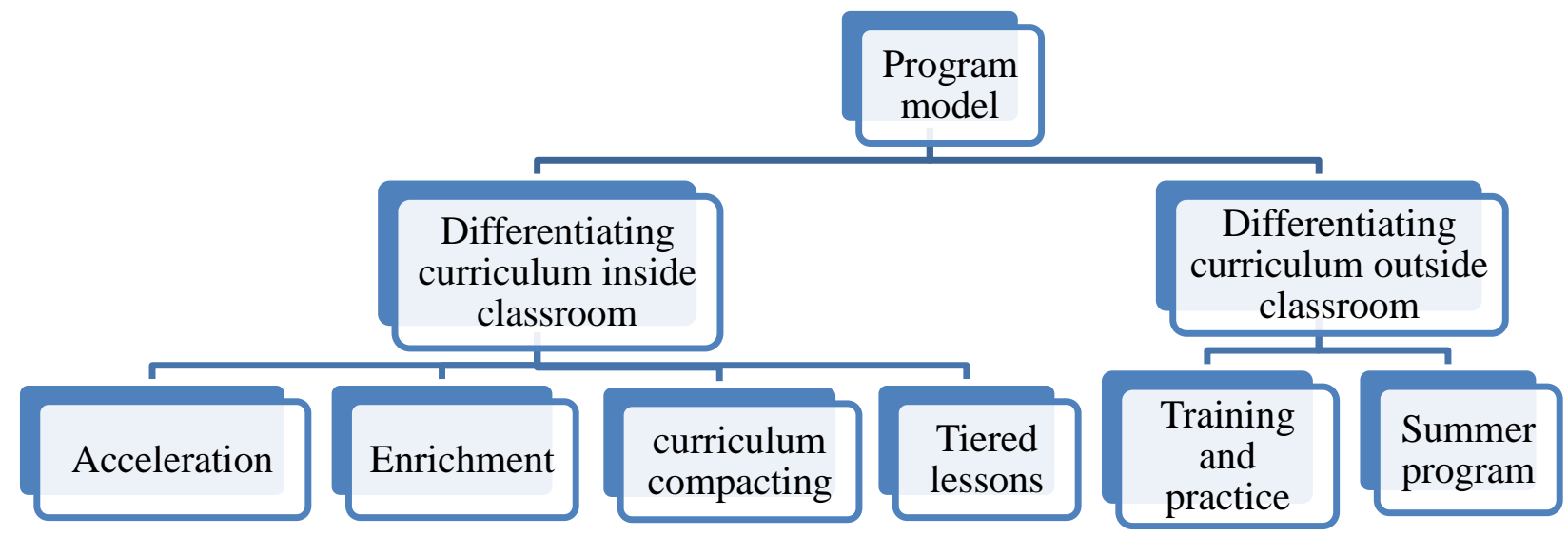

Figure 8: Program model

\section{Limitations of the Study}

Gifted programs are very important to reach out to talented ambitions and abilities, but some obstacles may stand as a barrier in front of these achievements. The teachers' capabilities to deal with these programs in the right way, and the lack of educational training around these programs create worry in terms of application and utilization. The restriction to the implementation of existing programs by the government in schools constitutes an obstacle to the introduction of new programs, especially those programs that need time; they have focused only on the academic achievement. Finally, the financial costs may prevent some schools from introducing these programs.

\section{Recommendation}

Based on the above findings, the program model should set clear-cut goals as an objective to be attained. As a start, the program is to provide an atmosphere for stimulating behavior among students who have been identified as requiring instruction that is qualitatively different from that of the regular curriculum. Moreover, it is supposed to provide opportunities for students to participate in guided investigative experiences, alone 


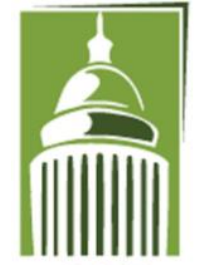

ARF

\section{Global Proceedings Repository \\ American Research Foundation}

ISSN 2476-017X

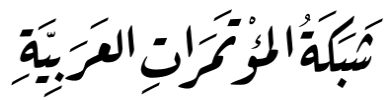

http://arab.kmshare.net/

Available online at http://proceedings.sriweb.org

and in small groups, using diverse human, material, and technical resources. It is also expected to provide opportunities for students to produce and evaluate products in areas of personal interests. Furthermore, it would implement the principles of divergent and convergent thinking, and serve as a resource to regular classroom teachers in the development of enrichment activities in both cognitive and affective areas.

\section{Comprehensive Identification Procedure}

The comprehensive identification procedure follows six key phases which are: teacher's nomination, peers' nomination, parents' nomination, gifted child interview, and identification through the group intelligence testing (see Figure 9 below). In the frame of such a method of identification, the following shall be used: the Raven Test, identification through Torrance Test of Creative Thinking (Torrance, 1966) determination of the academic achievement level through the academic skills standards, and the application of available monitoring lists in addition to the study of the cumulative grades record for students under identification.

Furthermore, individual intelligence tests can be used in order to study the relationship between IQ (Intelligence Quotient) as obtained by an individual in the Group Intelligence Testing (such as Raven's Progressive Matrices Test) and between IQ obtained by that individual in the individual intelligence tests (such as Wechsler's test and StanfordBinet's Test).

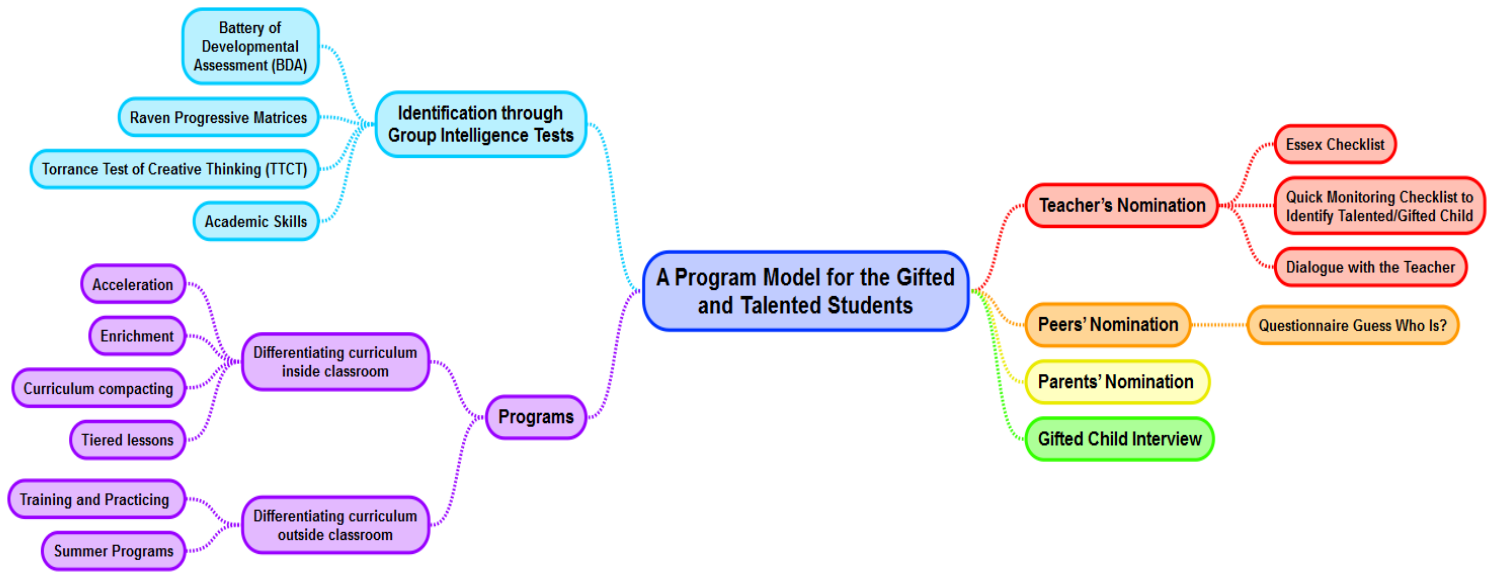

Figure 9: A program model 


\section{Global Proceedings Repository \\ American Research Foundation}

ISSN 2476-017X

Available online at http://proceedings.sriweb.org

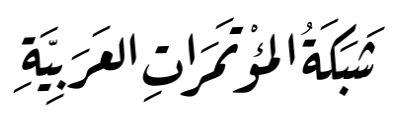

http://arab.kmshare.net/

AR F

Teacher's nomination. The teacher's nomination of a child as being talented/gifted child is considered among the most popular methods of talented identification, although it is less stable and honest than the well-known intelligence tests (Davis \& Rimm 2004). However, the problems associated with honesty can be overcome through developing monitoring checklists and questionnaires that can be prepared according to solid and accurate scientific foundations, then train teachers on how these questionnaires can be used when selecting the candidate students to be considered as talented/gifted child.

In fact, these monitoring checklists came as a result of the concerted efforts based on well-established deep literature and experience in this field. One of the most prominent lists, known as Essex Checklist, is a good example. To prepare this checklist, a group of teachers in Essex Primary Schools in Britain extracted items that they developed in their lists through in-depth and analytical experience and reading of the available literature. Such items are randomly listed rather of being classified according to their relative importance.

Model 1: the Essex checklist. It consists of the following:

- $\quad$ Possesses extensive general knowledge

- Has quick mastery and recall of information

- Has exceptional curiosity

- Shows good insight into cause and effect relationship

- Asks many provocative searching questions

- $\quad$ Easily grasps underlying principles and needs the minimum of explanation

- Quickly makes generalizations

- Often seeks unusual, rather than conventional relationships

- Listens to only part of an explanation

- Jumps stages in learning

- Leaps from the concrete to the abstract

- Is a keen and alert observer

- $\quad$ Sees greater significance in story or film etc...

- When interested becomes absorbed for periods

- Is persistent in seeking task completion

- Is more than unusually interested in adult problems such as religion, politics etc... 


\section{Global Proceedings Repository \\ American Research Foundation}

ISSN 2476-017X

Available online at http://proceedings.sriweb.org

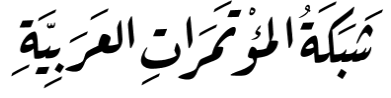

http://arab.kmshare.net/

ARF

- Displays intellectual playfulness: fantasizes, imagines, manipulates ideas

- Is concerned to adapt and improve institutions, objects, systems

- $\quad$ Has a keen sense of humor: sees humor in the unusual

- $\quad$ Appreciates verbal puns, cartoons, jokes etc....

- Criticizes constructively

- Is unwilling to accept authoritarian pronouncement without critical examination

- Has faster mental speed than physical capabilities

- $\quad$ Prefers to talk rather than write

- Day dreams

- $\quad$ Reluctant to practice skills already mastered

- $\quad$ Reads rapidly and retains what is read

- Has advanced understanding and use of language

- Shows sensitivity

- Shows empathy towards others

- $\quad$ Sees the problem quickly and takes the initiative

Model 2: quick monitoring checklist to identify a talented/gifted child. Try to write the names of the first three children you think they have the below traits, as this child (Davis and Rimm, 2004):

- Learns quickly

- Has the originality, the ability of imagination and creativity

- Has in-depth information

- Is persistent, resourceful, independent in his thinking

- $\quad$ Enjoys prudence and common sense

- Is a lover of research and investigation (curious and adheres to a schedule or arrangement)

- $\quad$ Has acceptable information about unfamiliar aspects or areas

- $\quad$ Has a sense of art

- $\quad$ Fluent and has a high linguistic inventory

- $\quad$ Has a musical trend and musical interests

- Is an Initiator and is independent in work

- $\quad$ Is logical and has a strong argument 


\section{Global Proceedings Repository \\ American Research Foundation}

ISSN 2476-017X

Available online at http://proceedings.sriweb.org

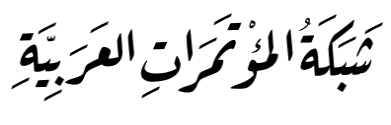

http://arab.kmshare.net/

- Is flexible and open-minded

- Is multi-talented and has many interests

- $\quad$ Shows an ability to intuition and insight

- Is passionate and has a high level of sensitivity

- Is of good humor

If the identification is carried out by a foreign party (not a school member), and the teacher's nomination has been adopted as a method for talented detection, it is important to launch an in-depth dialogue with the teacher before applying the Model No. 2 in order to get some information about the talented student's teacher.

Model 3: dialogue with the teacher. In Model No. 3 there is a list of questions that can be the subject of dialogue between the investigator/researcher and the teacher.It consists of the following:

- $\quad$ How do you define giftedness?

- In what area do you think the child is gifted?

- What triggered your attention to that child? Who is the first person to consider the child as talented/gifted?

- How is giftedness manifested in that child?

- What does the child want as a class member?

- What does the child want in his personal capacity?

- Is this person suffering from any problems?

- $\quad$ Do the rest of students see this gifted child?

- What are the special interests of this student?

- How do you organize your class?

- What curriculum is followed by this student?

- What educational subject matters do you think are useful for teaching gifted students?

- $\quad$ Are you following any special methods with the gifted student?

- Are there any readings or information you heard that impressed your idea about gifted students?

- What do the gifted child's parents desire?

- Would you like to have a gifted child?

- How do you distribute your time in the class among the various students?

- How do you rate the academic level in relative terms among your class students?

- How are seats distributed among classroom students?

- Is there consistency between the students in terms of abilities? 


\section{Global Proceedings Repository \\ American Research Foundation}

ISSN 2476-017X

Available online at http://proceedings.sriweb.org

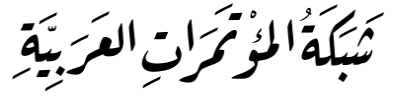

http://arab.kmshare.net/

A R F

- Were the gifted child's parents informed about their child's giftedness?

- Did you or anyone else suggest to grant him a scholarship or to refer him to a gifted children's school?

- What was your major, and how many years of experience do you have in the field of education?

- What educational qualifications (degrees) do you have?

Peers' Nomination. The peers' nomination method is considered the second step in the multi-standard gifted children's identification process. This method presents an acceptable degree of honesty and efficiency since peers have a good ability to know and assess their comrades. We can take advantage of this method by asking the students directly about their peers who have higher ability of achievement, about those who have leadership qualities and those with great innovation ability.

It should be noted in this regard that the peers' nomination should be done in an orderly and controlled manner, subject to a set of standards if it is intended to result in fruitful rewarding. As a result, a special questionnaire was developed and which could be distributed to students at any study age or class. The teacher should ask peers to read every sentence in the model, guess the name of the person to which that sentence applies, and write down the name in the space provided.

Model 4: questionnaire guess who is? It is as follows:

Name:

Sex:

Age:

School:

Date:

The following tries to portray a person or people you may know. Read each sentence and try to guess the name of the person to whom it may apply. You may be that person. There may be more than one sentence that applies to a single person, or more than one person may apply to a sentence, or the sentence may not apply to any of your peers.

Read each sentence keeping your peers in mind, and after you finish reading the sentence, write - in the space - the name of the person (girl or boy) whom that sentence describes (Eisenberg and Epstein 1981).

- $\quad$ This person laughs a lot and seems constantly fun and happy.

- $\quad$ This person is always very sad and seems constantly miserable and unhappy.

- $\quad$ This person likes to play a lot and finds the majority of games easy.

- $\quad$ This person works hard and actively and prefers to work rather than play. 


\section{Global Proceedings Repository \\ American Research Foundation}

ISSN 2476-017X

Available online at http://proceedings.sriweb.org

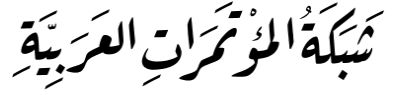

http://arab.kmshare.net/

A R F

- $\quad$ This person accomplishes work quickly, without facing any difficulties.

- This person causes too much trouble for the teacher, as if the troubles are following that person wherever he goes.

- $\quad \mathrm{He} / \mathrm{She}$ masters any work he carries out although he does not make a great effort to accomplish it

- He/She finds his academic duties easy and it almost seems that he does not make any effort to accomplish it.

- It is difficult to adapt with this person even if you tries so hard.

- $\quad$ This person believes he knows everything and spends a long time in showing-off.

- $\quad$ This person has extensive knowledge but does not brag. He is modest and shy.

- $\quad$ This person tries to manage things. He does anything he is asked to without being subject to any harm.

- This person is a leader in managing others. He leads everyone in the yard, arranges and conducts games.

- This person takes a large part of the teacher's time and asks the teacher to give him attention.

And now, write down the results obtained in Form No. 4, and compare these results with those obtained in Form No. 2.

When you write these results, you will be able to understand the multi-standard diagnostic process, and to recognize the scientific foundations upon which this process is based. This process mainly aims at detecting every individual having a talent, so that he is not deprived of opportunities available to the gifted and talented. Therefore, if the teacher's nomination method fails, the peers' nomination may succeed, and vice versa.

\section{Parents' Nomination}

If the person in charge of the process of gifted children's identification is a researcher or a teacher, and he wishes to benefit from the parents' information and make it part of the identification process he is carrying out, he should send a letter to the parents explaining what he intends to do and the services he wishes to provide to the child. In this letter, he shall state that he needs some information. The task can be facilitated, if he sends to the parents a model form to be filled for this purpose. The following points are helpful to formulate the model.

- $\quad$ Position of the child among his family members, and the number of family members; both boys and girls 


\section{Global Proceedings Repository \\ American Research Foundation}

ISSN 2476-017X

Available online at http://proceedings.sriweb.org

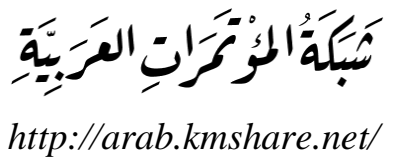

http://arab.kmshare.net/

A R F

- $\quad$ Occupation of the father/Occupation of the mother

- $\quad$ Number of hours both parents or each one of them spends with the child

- The child's interests and hobbies

- $\quad$ Kind of books he enjoys reading

- $\quad$ Acts and activities he practices that reflect a talent and creativity

- $\quad$ Features that the parents think reflect a talent and creativity

- Opportunities given to the child to excel at

- $\quad$ Activities the child prefers when he is alone

- Nature of the child's relationship with others inside and outside the house

It should be noted in this regard that some families might not be able to allocate enough time to spend with their children to be familiar with their talents and activities, which means that the researcher or scholar may not rely on the parents' views since they do not always know their children well, and their opinions may be confusing and inaccurate. On the other hand, there are families that deliberately exaggerate their expectations of their children and thus all children are regarded as gifted and talented. In this case, the parents' nomination is similarly negative and damaging as the previously mentioned kinds of families.

In brief, the person in charge of the multi-standard diagnostic process must be reliable and credible to investigate the style of the family he/she wishes to communicate with, to meet the family members to get all information that covers the aforementioned themes. He should not be frustrated if he could not obtain information from the parents. There are other methods that he can build upon and use.

\section{Gifted Child Interview}

The teacher may ask the gifted child questions about the talent and creativity aspects that she/he believes he possess. It may be useful to note that this interview method with the gifted child has proven to be very effective in the identification process of gifted in advanced stages of age.

As for the interview and its main themes, it is recommended to review Model 5, which is a practical guide developed with the aim of identifying the interview paths. This model includes 18 questions, formulated in the form of interview guidelines with the gifted child. The interviewer should not be distracted by the immediate noting of the answers; a recorder could be used to write a summary of the answers, and later on he can focus on each answer. However, he must not interact with the interviewee to make the interview as 


\section{Global Proceedings Repository \\ American Research Foundation}

ISSN 2476-017X

Available online at http://proceedings.sriweb.org

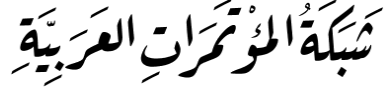

http://arab.kmshare.net/

natural as possible. The interviewer may find himself compelled to simplify the questions or explain them so that the interviewee may answer the questions, or he may add other questions due to the interview process.

Model 5: Gifted Child Interview Guide. It consists of the following:

- $\quad$ Do you have a brother or a sister? How old are they?

- Which activity do you prefer the most to do at school?

- With whom do you prefer to play at school?

- If you have the choice to be another student in your same class, which student do you choose? And Why?

- Which activity do you prefer the most to do outside the school?

- Which TV channel do you watch?

- Which kind of books do you read?

- How many hours do you read daily or weekly?

- $\quad$ Are you a member of a library? How many times do you visit the library?

- $\quad$ (For the children of minor age) Do you read to your mother? Does your mother read to you?

- When do you sleep?

- How do you spend the weekends?

- Are you a member in a club?

- Do you have any hobbies?

- What hobbies do you wish to practice?

- Do you play any musical instruments?

- With whom do you play out of school?

- What do you want to do after school graduation?

Identification through Group Intelligence Tests

There are many Group Intelligence Tests, but Lebanon and the Arab World are suffering from a dearth of developed and standardized Group Intelligence Tests to be applied. It is noted in this regard the great efforts made by a number of Arab educational psychologists in this field. However, the Battery of Developmental Assessment (BDA) 


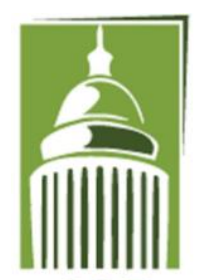

ARF

\section{Global Proceedings Repository \\ American Research Foundation}

ISSN 2476-017X

Available online at http://proceedings.sriweb.org

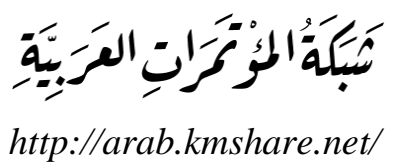

http://arab.kmshare.net/

remains the most prominent test and standardized to be applied on gifted and talented Lebanese students.

Battery of Development Assessment. The Battery of developmental Assessment (BDA) is a dynamic tool that views development as a continuous process. Ithas been developed to meet the needs of the Arab student populations. Since local research has revealed that the number of students with special needs is increasing, it was necessary to develop a practical battery of assessment that consists of tests, subtests, and checklists, that identify the abilities of those students, discover their various needs, and provide appropriate Individual Educational Plans (IEPs), and the counseling services needed (Husseini Bibi, 2005). Students with special needs may be gifted or talented, or twice exceptional, or suffer from deficits in comprehension or perceptual skills.

The BDA follows a developmental model of assessment. Itis a new approach designed for the purpose of evaluating the students' abilities and developmental needs. More specifically, it explores their readiness, cognitive abilities, psychological needs, and academic performance. Overton (2000) stated that by following a developmental model, the educator would be capable of preventing specific learning difficulties and psychological problems from occurring. It is important to note that the BDAhas been developed as a culture fair assessment tool, standardized to meet the norms of the Arab student populations.

The BDA differs from most assessment tools in that it focuses on qualitative rather than quantitative data. Most of the subtests are descriptive, and their credibility does not depend on raw scores or data. These descriptive measures aim at understanding the child from a developmental perspective. The BDA tests and subtests are varied, easy to administer, and are developed to suit the needs of diverse Arab populations and cultures, allowing more time for the child to respond and interact. The child is viewed as a partner and an active participant in the assessment process, as well as in the counseling process. The BDA does not focus solely on the child's weaknesses and problems, but rather helps in identifying strengths and positive traits as well. Moreover, it links assessment to learning, providing the educator with clues and directions in accommodating curriculum content, and in designing suitable teaching strategies.

Children with Special Needs deviate from the normal curve in one or more of the following developmental domains: cognitive, linguistic, emotional, and sensory-motor. Some could be experiencing some learning difficulties, sensory-motor deficits, auditory or visual perception problems, problems with adaptive behavior, or suffering from speech and language disorders, which may lead to school delay (Alroosan, 1996), while others may be experiencing frustration and boredom in classrooms, as the result of the presence of a certain gift or talent. 


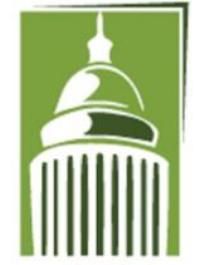

ARF

\section{Global Proceedings Repository \\ American Research Foundation}

ISSN 2476-017X

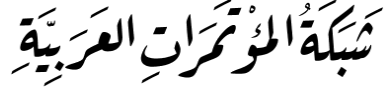

http://arab.kmshare.net/

Available online at http://proceedings.sriweb.org

The BDA is made up of three parts. The first part consists of 10 readiness and ability tests and subtests measuring multiple abilities, such as general knowledge, logical thinking, memory, sensory, motor, visual, and linguistic skills (Mashmoush, 1993). The second part focuses on the developmental needs and the psychological health of children, specifically those children with special needs; as it is believed that the environment plays a major role in the development of any individual's well being (Azayat, 1998). Finally, the third part consists of academic achievement tests of two core subject matter (Arabic and Math), that are curriculum based referenced tests (Azoyoud \& Ulayan, 1998).

The Raven Progressive Matrices. One may ask: Why should one use the Group Intelligence Test? The answer to this question relies on the personal knowledge of the foundations on which the multi-standard diagnostic process is based to detect gifted children accurately. The multi-standard diagnostic process passes through two phases. The first is the scanning and the second is the accurate identification. Since it is likely that the scanning process may nominate gifted children, but in fact they are not. Yet, that is to be expected in fast scanning processes. The scanning processes have their tools, among which the Group Intelligence Tests. In this context, the Raven's Progressive Matrices shall be classified. The Raven's Test is not classified randomly in the multi-standard diagnostic process, but it comes in the light of the definition he adopted and which indicated that the gifted child's IQ is high. Thus, to diagnose the gifted based on the IQ standard; one should use the intelligence tests, but not just any tests. Therefore, the use of the Group Intelligence Test which has been developed and codified to be used in the Arabic environment is recommended. Figure 10 below shows an example of a task from Raven.

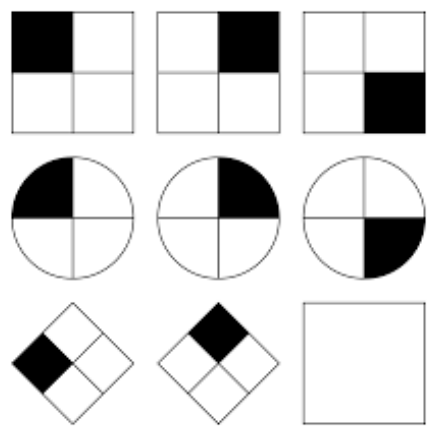

Figure 10: Raven's progressive matrices example 


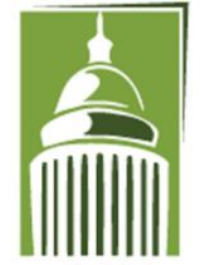

ARF

\section{Global Proceedings Repository \\ American Research Foundation}

ISSN 2476-017X

Available online at http://proceedings.sriweb.org

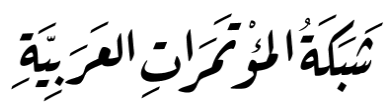

http://arab.kmshare.net/

Torrance Test of Creative Thinking. The Torrance Test of Creative Thinking (TTCT) appeared in the United States in the late sixties of this century. It is used to measure the creative thinking ability of students by more than one method. There is the verbal image of the test, and the forms (form picture). The verbal image consists of seven subtests, each as a sub-activity. It requires writing of questions, and putting speculation for reasons or results, improving the production, and proposing alternative uses for certain things, or making assumptions to unexpected situations. However, all of these alternatives involve creative and original thought. As for the form picture of the test, it consists of three tests. Each serves as an activity that requires the drawing of a topic or topics on a closed or open line, or on an incomplete line. All these required issues are, however, uncommon patterns.

There are also pictures of this test translated into Arabic with an acceptable degree of reliability and validity. They can be used to identify those with high ability of creative thinking. One can apply the Torrance Test individually or collectively as he pleases and at all age levels, with the possibility of verbal image test usage with people who are of an educational level lesser than the fourth grade level, provided it is applied individually in this case.

This test has a special booklet explaining the instructions of application and subtests. Achievement tests are considered one of the most common tests, which are of three main types: diagnostic tests, survey tests, and readiness tests in some fields. The general achievement and the private achievement tests batteries can be also added. Figure 11 below is an example.

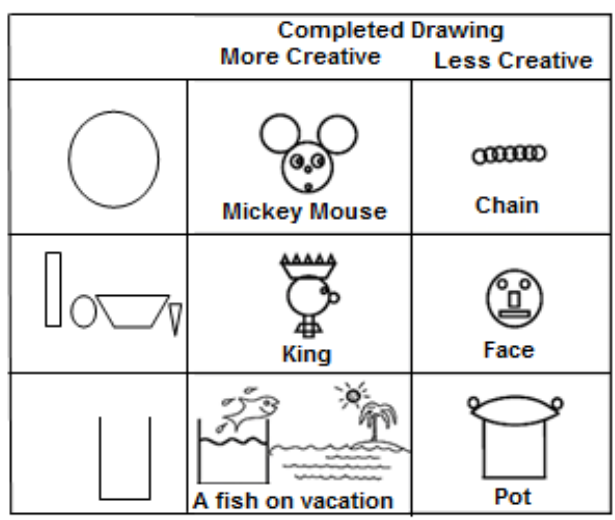

Figure 11: Torrance test of creative thinking example 


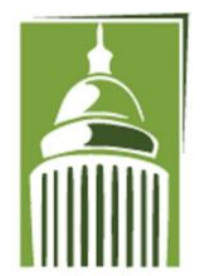

ARF

\section{Global Proceedings Repository \\ American Research Foundation}

ISSN 2476-017X

Available online at http://proceedings.sriweb.org

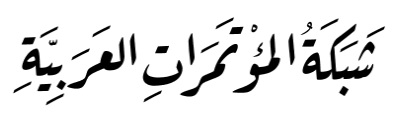

http://arab.kmshare.net/

Academic Skills. The following tests can be used:

The General Achievement Test batteries. They can be used with the interviewees of different levels starting with the primary level till the high studies level. They vary in terms of nature of materials and the interviewees' level, as well as the difference in standards and its validity and reliability standards.

The Metropolitan tests. They are of the most commonly used tests batteries. They can be used with interviewees of different levels as of the primary education till the end of the preparatory cycle.

Stanford-Binet Achievement test. It is among the oldest achievement codified tests, which may be used starting from the second class of the primary cycle till the end of the preparatory cycle.

California Achievement tests. They measure the students' achievement as of the first primary class till the third secondary class. They are distributed into four batteries sharing the measurement of five fields: reading vocabulary, understanding the read material, the arithmetic inference, the mathematical foundations, and the language.

Among the private codified achievement tests, the following are noted: Gates Reading Readiness Tests, Metropolitan Tests for the same purpose, Monroe Tests to Prepare for Reading, and the Iowa Silent Reading Test.

\section{Program Model}

Differentiating curriculum inside classroom. The following methods are used for withinclass differentiation:

Acceleration. Not abiding by the educational plan and allowing the superior students to pass the educational stage in faster pace than usual, providing them with educational and learning experiences given usually to elders, accelerating the content of normal teaching without any change in teaching methods or content subjects, and giving them freedom and flexibility to move to other higher programs and skills each time they are done with the recent educational objectives stage.

Enrichment. Inserting certain adjustments and additional points to the assigned curricula for normal students in the fields of knowledge, interaction, creativity, motion; increasing the level of difficulty in the traditional educational subjects, and diving deeply in one or more of the teaching subjects. It could be vertical enrichment: the process of enriching the 


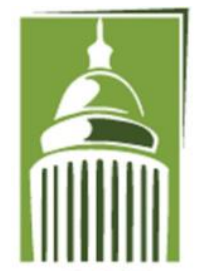

A R F

\section{Global Proceedings Repository \\ American Research Foundation}

ISSN 2476-017X

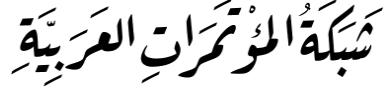

http://arab.kmshare.net/

Available online at http://proceedings.sriweb.org

curricula with certain experiences in one field of the subjects, or horizontal enrichment: where experiences are enriched in many scholastic subjects and themes.

Curriculum compacting. It involves compressing the instructional content and materials so that academically-able students have more time to work on more challenging materials.

Tiered lessons. They provide different extensions of the same basic lesson for groups of students of differing abilities, where three groups of students might work on follow-up activities or assignments of basic, middle, and high difficulty.

Differentiating curriculum outside classroom. The following methods are used for outside-class differentiation:

Training and practice. This method includes training and tutoring programs which allow students with exceptional talents to be exposed to one of the most powerful and proven educational strategies-modeling.

Summer programs. They include intense learning experiences that concentrate on specific areas of intellectual, artistic, or cultural affairs.

Finally, it is important to ensure that the program model meets the student's need and provides an appropriate level of academic challenge. Moreover, it should be followed by continuous monitoring of students development and evaluation of the program to ensure that curriculum modifications, and grouping or placement strategies continue to meet the needs of the identified gifted students. Monitoring and evaluation provide detailed information to assess the success of the program and inform about future planning. 


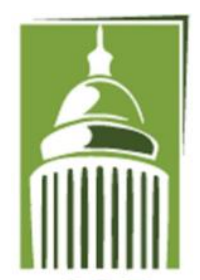

ARF

\section{Global Proceedings Repository \\ American Research Foundation}

ISSN 2476-017X

Available online at http://proceedings.sriweb.org

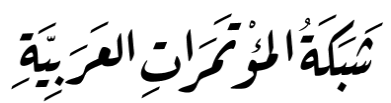

http://arab.kmshare.net/

\section{References}

Alroosan, F.(1996). Methods of assessment and diagnosis in special education. Dar Al fikr, Amman.

American Association of State Highway and Transportation Officials (2000). Transportation Invest in Our Future: A New Vision for the 21st Century. Washington, D.C.

Azayat, F.(1998). Learning difficulties: theory, diagnosis and therapy. Cognitive Psychological Series 4, Education Department, Almansoura University, Egypt.

Azoyoud, N. F. \& Ulayan, H. A.(1998). Principles of educational tests and measurements, Dar Al fikr, Amman.

Bloom, B. (Ed.) (1985). Developing Talent in Young People. New York: Ballantine Books.

Coleman, M. (2003) 'The Identification of Students Who Are Gifted', ERIC Digest. VA; Arlington: ERIC Clearinghouse on Disabilities and Gifted Education. Obtained online from www.eric.ed.gov Last access in 11-8-2016.

Connelly, F. M., \& Clandinin, D. J. (1988). Teachers as curriculum planners: Narratives of experience. New York: Teachers College Press.

Cramond, B. (2004) 'Can We, Should We, Need We Agree On A Definition Of Giftedness?', Roeper Review. Vol. 27, No.1, pp. 15-16

Davis, G. A., \& Rimm, S. B. (2004). Education of the gifted and talented(5th ed.). Boston: Pearson Education.

Delisle, J., and Berger, S., 1990. Underachieving gifted students. ERIC digest \#E478. Available from: http://www.kidsource.com/kidsource/content/underachieving_gifted.html Last access in 11-8-2016.

Eisenberg, D., \& Epstein, E. (1981, December). The discovery and development of giftedness in handicapped children. Paper presented at the CEC-TAG National Topical Conference on the Gifted and Talented Child, Orlando, FL.

Feldhusen, J. F., \& Jarwan, F. A. (2000). Identification of gifted and talented youth for educational programs. In K. A. Heller, F. J. Monks, R. Sternberg, \& R. F. Subotnik (Eds.),International handbook of giftedness and talent (pp. 271-282). Oxford: Pergamon. doi:10.1016/0022-4405(80)90060-6.

Freeman, J. (2000) Educating the Very Able. London: The Stationery Office.

Friend, M. (2008). Special Education: Contemporary Perspectives for School Professionals(2nd ed.). USA; Pearson Education Inc.

Gagné, F. (1991) Toward a differential model of giftedness and talent. In N. Colangelo and G.A. Davis (Eds.) Handbook of gifted education. Boston, MA: Allyn \& Bacon. 


\section{Global Proceedings Repository \\ American Research Foundation}

ISSN 2476-017X

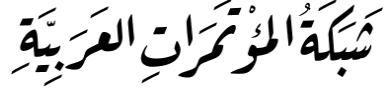

http://arab.kmshare.net/

AR F

Available online at http://proceedings.sriweb.org

Gagné, F. (1995). From giftedness to talent: a developmental model and its impact on the language of the field. Roeper Review, 18, 103-111.

Gagné, F. (1993). Constructs and models pertaining to exceptional human abilities. In K. A. Heller,F. J. Monks, \& A. H. Passow (Eds.), International handbook of research and development of giftedness and talent (pp. 63-85). Oxford: Pergamon Press.

Gagné, F. (2000). Understanding the complex choreography of talent development through DMGT-based analysis. In K. A. Heller, F. J. Monks, R. Sternberg, \& R. F. Subotnik (Eds.), International handbook of giftedness and talent (pp. 67-79). Oxford: Pergamon.

Gallagher, J. (1984). Excellence and Equity-A Worldwide Conflict. Gifted International, 2 (2), 1-11.

Gallagher, J.J. (1985). Teaching the Gifted Child (3rd ed.). Boston, MA: Allyn \& Bacon.

Gallagher, J. (1994) 'Current and Historical Thinking on Education for Gifted and Talented Students'. In : National Excellence: A Case for Developing America's Talent. An Anthology of Reading. Ross, P. (ed) Washington DC: Office of Educational Research and Improvement, pp. 83-107.

Goodlad, J. (1964). School Curriculum Reform in the United States. New York: Fund for the Advancement of Education.

Heller, K. A. (1990). Goals, methods and first results from the Munich Longitudinal study of giftedness in West Germany. In C. W. Taylor (Ed.), Expanding awareness of creative potentials worldwide (pp. 538-543). Salt Lake City: Brain Talent-Powers Press.

Heller, K. A. (1991). The nature and development of giftedness: A longitudinal study. European Journal of High Ability, 2, 174-188.

Heward, W.L.(2006). Exceptional Children: An Introduction to Special Education (8th ed.). New Jersey: Merill Prentice Hall.

Husseini Bibi, H. (2005). Battery of Developmental Assessment (BDA): An assessment kit with tools to describe abilities, academic skills, and psychological health of Arab children. Irshad, Beirut \& Dar Okaz, Jeddah.

Knudson, D. (2006). Gifted education in New Zealand primary schools 1878-2005. Wellington, New Zealand: NZCER Press.

Ladson-Billings, G. (1995). Toward a Theory of Culturally Relevant Pedagogy. American Educational Research Journal, 32, 465-491.

Maker, C. J. \& Schiever, S. W.(2005). New directions in enrichment and acceleration. In N. Colangelo \& G. A Davis (Eds.),Handbook of gifted education (3rd ed., pp. 163173). Boston: Allyn \& Bacon. 


\section{Global Proceedings Repository \\ American Research Foundation}

ISSN 2476-017X

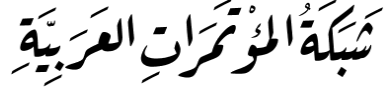

http://arab.kmshare.net/

AR F

Available online at http://proceedings.sriweb.org

Marland, S. P. (1972). Education of the gifted and talented. (2 Vols.). Report to congress of the United States Commissioner of Education. Washington, DC: US Government.

Mashmoush \& Others (1993). Educational assessment. Dar Okaz, Riyad.

McCoach, D. B., \& Siegle, D. (2003). Factors that differentiate underachieving students from achieving students. Gifted Child Quarterly, 47, 144-154.

Ministry of Education. (2001). Working Party on Gifted Education: Report to the Minister of Education. Wellington, New Zealand: Ministry of Education.

Ministry of Education. (2012). Gifted and Talented Students: Meeting Their Needs in New Zealand Schools. Wellington, New Zealand: Ministry of Education.

National Center for Educational Research and Development. (1995). Lebanese National Curriculum. Beirut: Lebanon.

National Association for Gifted Children. (2011). Redefining giftedness for a new century: Shifting the paradigm [Position Paper]. http://www.nagc.org/sites/default/files/Position\%20StatementPrinting Office. (Government Documents, Y4.L 11/2: G36). Last access in 11-8-2016

Overton, T.(2000). Assessment in special education, Merrill, Prentice Hall, New Jersey.

Piaget, J. (1958). The growth of logical thinking from childhood to adolescence. $A M C, 10$, 12.

Renzulli, J. (2001) 'Standards and Standards Plus. A Good Idea or a New Cage?', Gifted Education Communicator, Gosfield, M. (ed). California Association for the Gifted, V. 31, No.1, p. 10.

Renzulli, J.S. (2003). The school wide enrichment model: Developing creative and productive giftedness. In N. Colangelo, \& G.A. Davis (Eds.),Handbook of gifted education (3rd ed.), pp. 184-203. Boston: Allyn \& Bacon.

Robinson, H. (1977). Current Myths Concerning Gifted Children. Gifted and Talented Brief, 5,1-11. Ventura, CA: National/State Leadership Training Institute.

Rogers, K. (1986). Do the Gifted Think and Learn Differently? A Review of Recent Research and Its Implications. Journal for the Education of the Gifted, 10 (1), 1740.

Sarouphim, K. M. (2009). The use of a performance assessment for identifying gifted Lebanese students: Is DISCOVER effective? Journal for the Education of the Gifted, 32, 276-296.

Schunk, D. H. (1987). Peer models and children's behavioral change. Review of EducationalResearch, 57, 149-174.

Simi (1998). Claiming Disability: Knowledge and Identity. New York: New York University Press. 


\section{Global Proceedings Repository \\ American Research Foundation}

ISSN 2476-017X

Available online at http://proceedings.sriweb.org

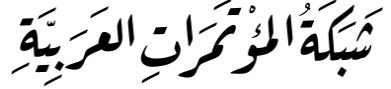

http://arab.kmshare.net/

A R F

Sternberg, R. J., \& Lubart, T. I. (1995). Defying the crowd : Cultivating creativity in a culture of conformity. New York: Free Press.

Szabos, J. (1989). Bright child, gifted learner. Challenge, 34.

Tannenbaum, A. (1983). Gifted Children. New York: MacMillan Publishing.

Terman, L. (1925). Mental and Physical Traits of a Thousand Gifted Children (Vol. 1). Stanford, CA: Stanford University Press.

Terman, L. \& Oden, M. (1947). The Gifted Child Grows Up (Vol. 4). Stanford, CA: Stanford University Press.

Terman, L. \& Oden, M. (1959). The Gifted Group at Mid-Life (Vol. 5). Stanford, CA: Stanford University Press.

Tomlinson, C. (2001). How to Differentiate Instruction in Mixed-Ability Classrooms (2nd ed.). Alexandria, VA: Association for Supervision and Curriculum Development.

Torrance, E. P. (1966). The Torrance Tests of Creative Thinking-Norms-Technical Manual Research Edition-Verbal Tests, Forms A and B-Figural Tests, Forms A and B. Princeton, NJ: Personnel Press.

Turnbull, R., \& Wehmeyer, L.M. (2007). Exceptional Lives: Special Education in Today's Schools (8th ed.). New Jersey: Merill/Prentice Hall.

Wehbi, S. (2006). The challenges of inclusive education in Lebanon. Disability \& Society, $21,331-343$.

Winstanley, C. (2004) Too Clever by Half: A fair deal for gifted children. London: Trentham Books.

Wong, M., \& Hansen, J. J. (2012). Pursuing the pot at the end of the rainbow? Provision for gifted and talented education in early childhood teacher education programmes in Aoteaora New Zealand. Tall Poppies Magazine of the New Zealand Association for Gifted Children, 37(2), 16-17.

Ziegler, A., \& Heller, K. A. (2000). Conceptions of giftedness from a meta-theoretical perspective. In K. A. Heller, F. J. Monks, R. J. Sternberg, \& R. F. Subotnik (Eds.), International handbook of giftedness and talent (pp. 3-21). Amsterdam: Elsevier. 


\section{Global Proceedings Repository \\ American Research Foundation}

ISSN 2476-017X

Available online at http://proceedings.sriweb.org

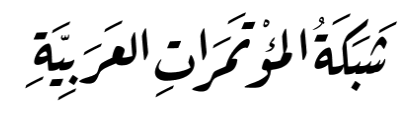

http://arab.kmshare.net/

Appendix 1: Questionnaire

\section{- Variables:}

- Gifted and talented students' definition

- Gifted and talented students' identification

- Gifted and talented students' needs

- $\quad$ Sample:

○ Teachers

- Pillars:

- $\quad \underline{\text { Effects }}$ of implementing programs for increasing gifted students ability

Opinion, if identification and program model should be integrated in schools or not

\section{$\underline{\text { Teachers' Profile: }}$}

1. Age:
1) $\quad 20-30$
2) $31-40$
3) $41-50$
4) $>50$

2) Gender:

$\begin{array}{ll}\text { 1) } & \text { 2) } \mathrm{M}\end{array}$

3) Years of Experience:

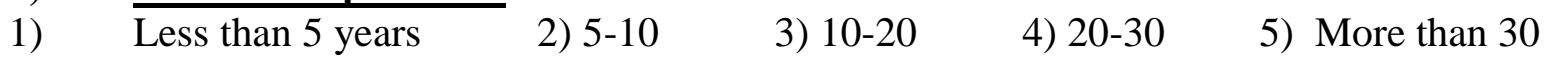
years

4) Academic Degree:
1) License
2) Master
3) $\mathrm{Ph} \mathrm{D}$
4) $T D$
5) M.Ed.

5) Classes You Teach:
1) Kindergarten
2) cycle 1
3) cycle 2
4) cycle 3
5)
Secondary level 


\section{Global Proceedings Repository \\ American Research Foundation}

ISSN 2476-017X

Available online at http://proceedings.sriweb.org

\section{Teachers' Questionnaire:}

\begin{tabular}{|c|c|c|c|c|c|c|}
\hline & & $\begin{array}{l}\text { Strongly } \\
\text { Disagree }\end{array}$ & 2. Disagree & $\begin{array}{l}\text { Neither agree } \\
\text { nor disagree }\end{array}$ & - Agree & $\begin{array}{l}\text { Strongly } \\
\text { Agree }\end{array}$ \\
\hline 6 & $\begin{array}{l}\text { Teachers often see gifted } \\
\text { children as annoying } \\
\text { students. }\end{array}$ & & & & & \\
\hline 7 & $\begin{array}{l}\text { Work that is too easy } \\
\text { frustrates gifted children. }\end{array}$ & & & & & \\
\hline 8 & $\begin{array}{l}\text { If not challenged, gifted } \\
\text { children's ability will be } \\
\text { weakened. }\end{array}$ & & & & & \\
\hline 9 & $\begin{array}{l}\text { Not all gifted children show } \\
\text { creativity. }\end{array}$ & & & & & \\
\hline 10 & $\begin{array}{l}\text { Not all gifted children } \\
\text { show leadership. }\end{array}$ & & & & & \\
\hline 11 & $\begin{array}{l}\text { Not all gifted children show } \\
\text { physical expertise. }\end{array}$ & & & & & \\
\hline 12 & $\begin{array}{l}\text { The regular curriculum in } \\
\text { use is suitable for all } \\
\text { learners including those } \\
\text { gifted and talented } \\
\text { students. }\end{array}$ & & & & & \\
\hline 13 & $\begin{array}{l}\text { There is a program for the } \\
\text { gifted and talented } \\
\text { students in my school. }\end{array}$ & & & & & \\
\hline 14 & $\begin{array}{l}\text { Gifted and talented students } \\
\text { require a differentiated } \\
\text { curriculum. }\end{array}$ & & & & & \\
\hline
\end{tabular}




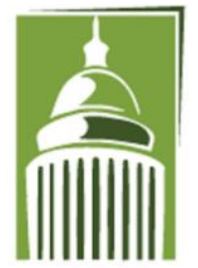

AR F
Global Proceedings Repository

American Research Foundation

ISSN 2476-017X

Available online at http://proceedings.sriweb.org

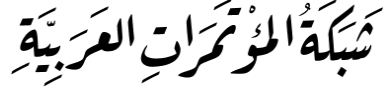

http://arab.kmshare.net/

\begin{tabular}{|l|l|l|l|l|l|}
\hline 15 & $\begin{array}{l}\text { Teachers describe gifted } \\
\text { and talented students as } \\
\text { high achievers. }\end{array}$ & & & & \\
\hline
\end{tabular}

\section{Appendix 2: An Interview with School Principals}

1. Interview with the Principal of Generations High School:

1. Do you think that the talented students are in need of special programs to deal with them?

Yes, talented students need two-side special care:

a- In terms of treatment method, for some are featured by high sensitivity causing them to observe certain situations accurately, and are very keen to understand everything happening around them. Therefore, we should always try to understand the psychological privacy for each one of them.

b- $\quad$ In terms of educational subjects and daily homework; we should perceive that they get ideas and understand lessons, rules and concepts faster them their peers. So, we have to provide them with certain explanation strategies fitting them and provide them with one question or more depending on subjects through evaluation.

2. Does your school follow special programs for talented and gifted students?

Our school has a certain plan for discovering the talented and gifted students, and it aims to set a special program to fit them.

3. How does the plan affect the performance of the students?

The plan does not affect the performance of the students as it takes into consideration the students' performance of their home work in its allotted time. It also prepares extra special homework for them other than their friends where a part is to be done within the recess or in some activity periods.

4. What problems does the teacher face while applying the program?

What the teacher faces is the lack of experience in this field and we aim to create and experiment to achieve the best.

5. Can we rely on certain programs taken from other countries and applying it in Lebanon?

We can examine similar experiences taken from other countries and benefit from it to develop our performance in order to be able to specialize a part in the annual plan for gifted and talented.

6. Are the teachers well-trained to use these programs in the class? 
Available online at http://proceedings.sriweb.org

They haven't been trained yet, but they get benefit from the personal experiences that Mrs. Amena Allouch had started (a previous teacher) where her plan is under development for the purpose of enhancing the experience. 


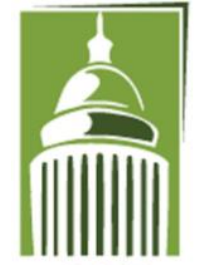

ARF

\section{Global Proceedings Repository \\ American Research Foundation}

ISSN 2476-017X

Available online at http://proceedings.sriweb.org

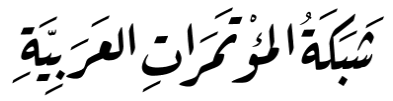

http://arab.kmshare.net/

2. Interview with the Principal of Safir High School:

1. Do you think that the talented students are in need of special programs to deal with them?

The talented child is special in his/her talent. He/She has certain intellectual features and traits. In fact, we believe that each child has the right to have a special program, and this is true for talented children in order to invest the potential talents they have and not to lose social energies. On the contrary, we change them into wonderful production.

2. Does your school follow special programs for talented and gifted students?

Frankly speaking, the school hasn't reached the point of setting out special programs for the gifted and talented, but it takes into consideration, to a great percentage, the situation of such a group of the students academically. A certain experimental project is being applied with grade 9 students in such a way that the students are divided into certain academic levels where a special program is prepared for the gifted. With respects to talents rather than the academic one, the school set a program based on forming clubs where talented students participate in clubs such as the acting club, the broadcasting club, the drawing club, the writing club, the scientific experiments' club...)

3. How does the plan affect the performance of the students?

Such programs have a great positive impact on the students because it is based on the student's talented (it is not imposed on him)

They affect:

1- $\quad$ his academic performance

2- $\quad$ his social communication becoming better

3- the development of values

4- $\quad$ the development of motivation

4. What problems does the teacher face while applying the program?

- $\quad$ Since the clubs are based on the student's talented and his tendency towards a specific hobby and since the objectives and activities are set for each club, then no problems are mentioned.

Academically, the problem could be summarized in preparing and training teachers to deal skillfully and intelligently with the talented students.

5. Can we rely on certain programs taken from other countries and applying it in Lebanon?

In fact, we can benefit from any experience in the world, but we can set a program and try it as well. Then, we can adjust it based on our social and intellectual needs.

6. Are the teachers well-trained to use these programs in the class?

Regarding clubs, everything is going on smoothly. As for academic performance, the idea is still in its infancy and the teachers are in need of continuous training in this field. 


\section{Global Proceedings Repository \\ American Research Foundation}

ISSN 2476-017X

Available online at http://proceedings.sriweb.org

Appendix 3: Recording Nomination Card

1. Recording

Nomination

1. Student name:

2. Teacher name:

3. Date of giving information:

4. School:

5. Grade:

6. Date of Birth:

7. Medium arrangements for the current school year:

8. Linguistic arts:

9. Social Studies:

10-mathematics:

11-Science:

12. Why do you think that this student should be attached to the power pack?

(You may wish to view examples of ideas and projects and innovative creative attempts ....)

13. Tick (X) in the item, which describes the best image of the pupil

5: Has this attribute a high degree

4: He has this attribute greater than the average child degree

3: It can be compared to a normal child

2: He has this attribute less than the average child

1: Lacking in this attribute

\begin{tabular}{|l|l|l|l|l|l|l|}
\hline Behavior & Characteristics and & $\mathbf{1}$ & $\mathbf{2}$ & $\mathbf{3}$ & $\mathbf{4}$ & $\mathbf{5}$ \\
\hline $\begin{array}{l}\text { * Sharp focus and attention organisms } \\
\text { and mutual interaction } \\
\text { * Can spans his attention for a long time }\end{array}$ & $\begin{array}{l}\text { Vigilance } \\
\text { awareness of unusual }\end{array}$ & & & & \\
\hline $\begin{array}{l}\text { *Develops at an earlier age } \\
* \text { Able to play games that require } \\
\text { strategy as early as compared to peers in } \\
\text { age }\end{array}$ & $\begin{array}{l}\text { Advanced behavior in } \\
\text { play }\end{array}$ & & & & & \\
\hline $\begin{array}{l}\text { * The ability to remember information in } \\
\text { great detail. } \\
\text { *Tells a lot of stories often with a } \\
\text { tremendous amount of detail }\end{array}$ & & & & & & \\
\hline
\end{tabular}




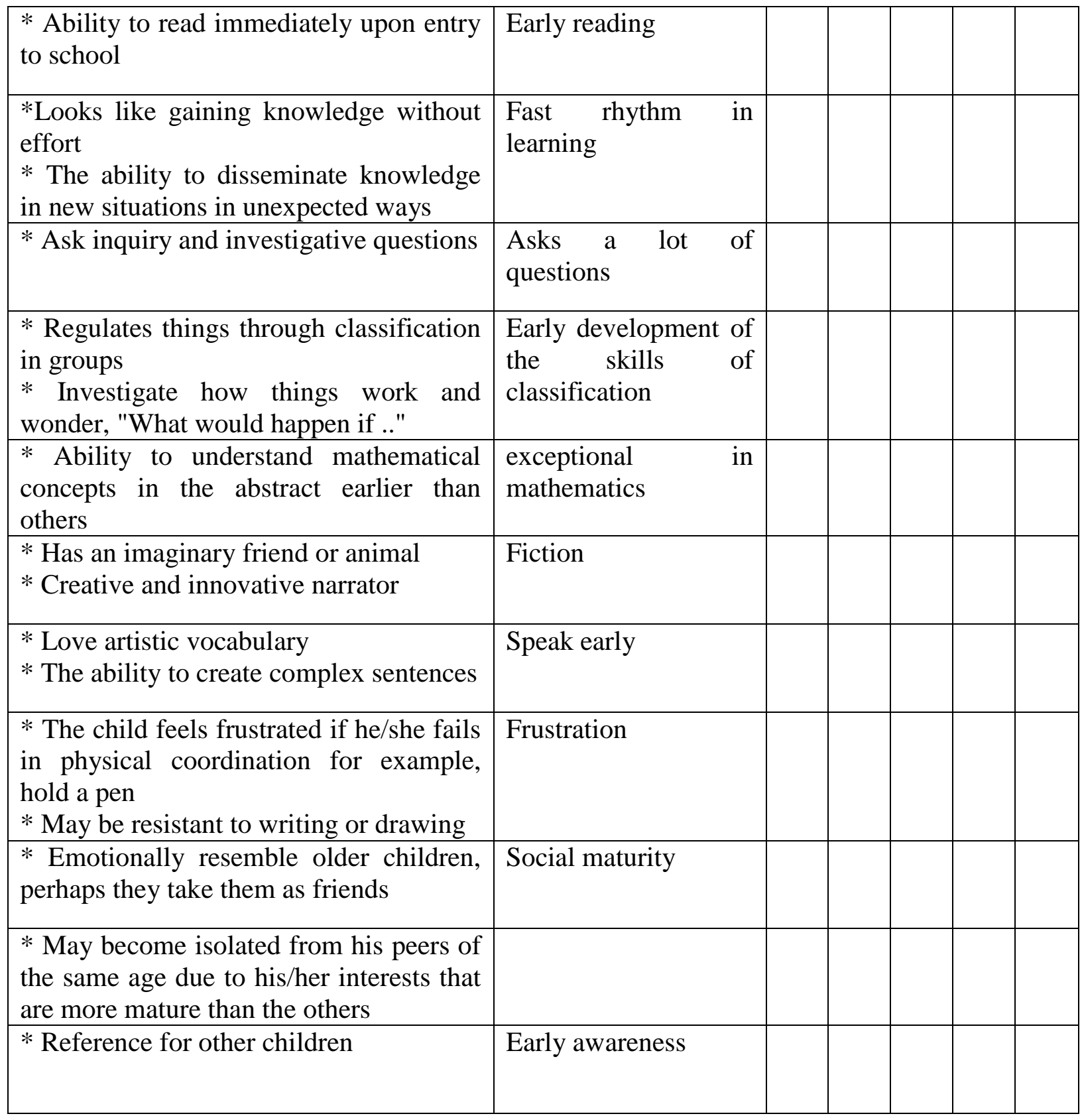




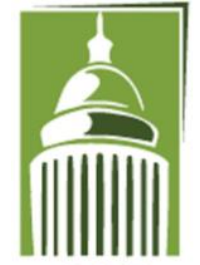

A R F

\section{Global Proceedings Repository}

American Research Foundation

ISSN 2476-017X

Available online at http://proceedings.sriweb.org

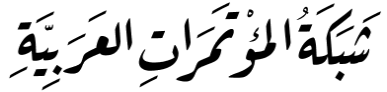

http://arab.kmshare.net/

* It may start to make mistakes deliberately to be like other children

\section{Recording Nomination Parents Card}

Tick (X) in the item, which describes the best image of the pupil

5: Has this attribute a high degree

4: He has this attribute greater than the average child degree

3: It can be compared to a normal child

2: He has this attribute less than the average child

1: Lacking in this attribute

\begin{tabular}{|c|c|c|c|c|c|}
\hline Behavior & 1 & 2 & 3 & 4 & 5 \\
\hline \multicolumn{6}{|c|}{ has advanced linguistic, he expresses himself well } \\
\hline \multicolumn{6}{|l|}{ thinks quickly } \\
\hline \multicolumn{6}{|l|}{ retrieves facts easily } \\
\hline \multicolumn{6}{|l|}{ wants to know how things work } \\
\hline \multicolumn{6}{|l|}{ read (before kindergarten starts) } \\
\hline \multicolumn{6}{|c|}{ collect ideas related to each different together in new ways } \\
\hline \multicolumn{6}{|l|}{ become bored easily } \\
\hline \multicolumn{6}{|l|}{ ask questions } \\
\hline \multicolumn{6}{|c|}{ loves "For Adults" things and to be with older people } \\
\hline it has a great deal of curiosity & & & & & \\
\hline
\end{tabular}




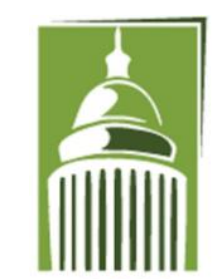

A R F
Global Proceedings Repository

American Research Foundation

ISSN 2476-017X

Available online at http://proceedings.sriweb.org

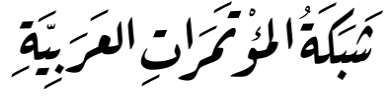

http://arab.kmshare.net/

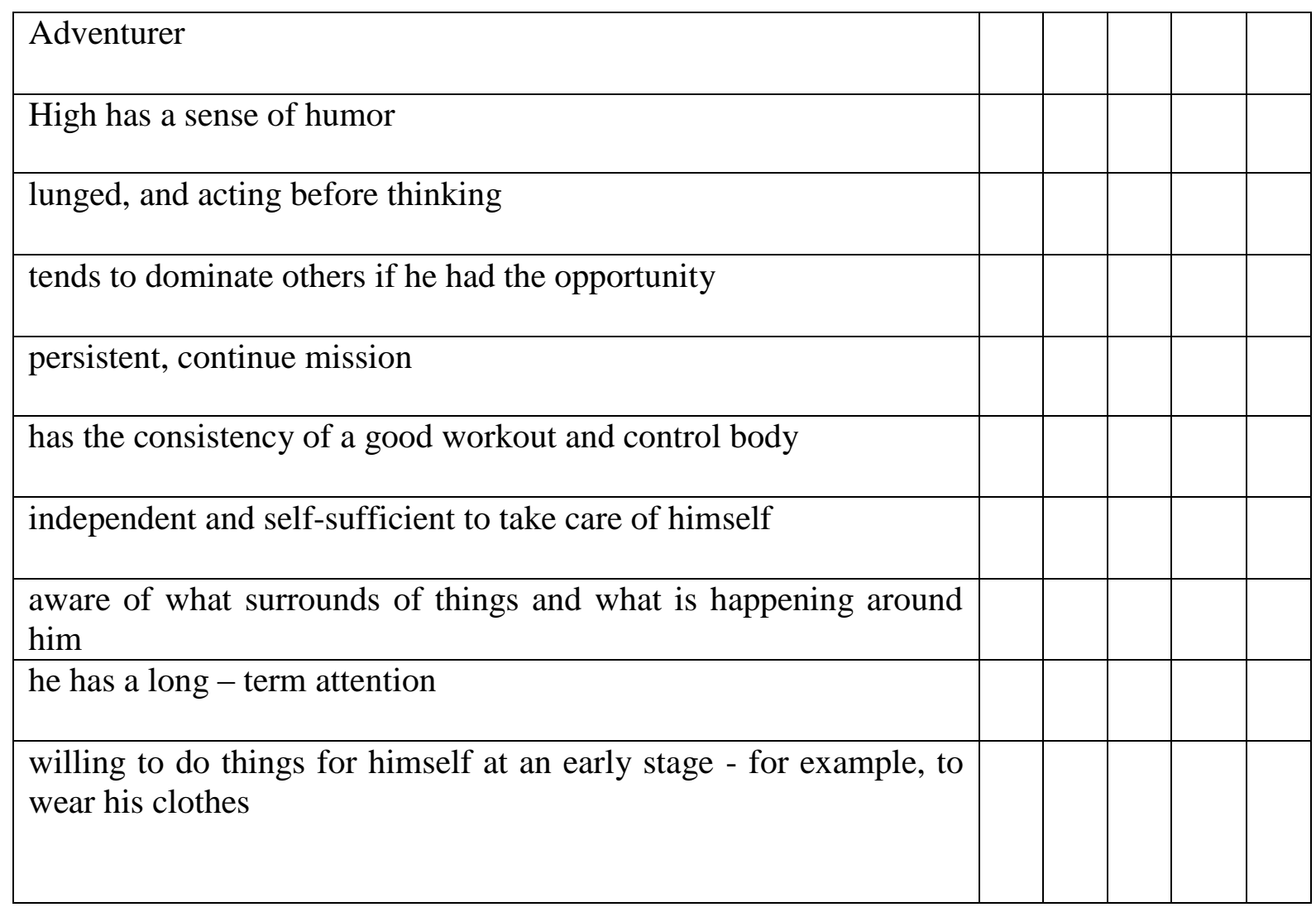




\section{Global Proceedings Repository \\ American Research Foundation}

ISSN 2476-017X

A R F

Available online at http://proceedings.sriweb.org

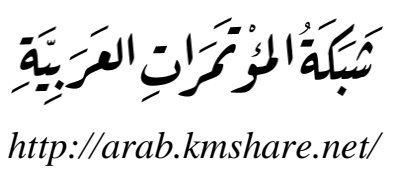

http://arab.kmshare.net/

\section{Appendix 4: BDA Test Result for Mouhamad Jawad Makka}

\section{BDA Result}

Among the 55 students which were nominated by the schools, only one student "Mouhamad Jawad Imad Makka" from Generations High School was identified as a gifted student. The BDA test showed that he has high intelligence and that his mental abilities are above the age of nine years old (see table 4 below). They are equivalent to the age of eleven years and a half. In addition to his high ability to focus, he is in the fifth grade level in arithmetics and mathematics. An Individual Educational Plans (IEP) was designed to meet his needs. The long-term objectives were to finish high school and go to university to achieve his ambitions of becoming a chemist. The short-term objectives were to set up an enrichment program and provide a resource room to allow him to discover a wide range of topics and practice using educational activities, all in order to set his creativity functioning.

\begin{tabular}{|l|l|l|l|l|l|l|l|}
\hline $\begin{array}{l}\text { Student's } \\
\text { Name }\end{array}$ & Grade & Age & $\begin{array}{l}\text { School } \\
\text { Average } \\
\mathbf{/ 1 0 0}\end{array}$ & $\begin{array}{l}\text { General } \\
\text { knowledge } \\
\mathbf{/ 1 0 0}\end{array}$ & $\begin{array}{l}\text { Thinking } \\
\text { Skills } \\
\mathbf{/ 9 3}\end{array}$ & $\begin{array}{l}\text { Math \& } \\
\text { Logic } \\
\mathbf{/ 1 2 5}\end{array}$ & $\begin{array}{l}\text { Mental } \\
\text { age }\end{array}$ \\
\hline $\begin{array}{l}\text { Mouhamad } \\
\text { Makka }\end{array}$ & 3 & $9 \mathrm{y} .1 \mathrm{~m}$ & 18.8 & 92 & 91 & 123 & $\begin{array}{l}11 \mathrm{y} .5 \mathrm{~m} \\
\text { Gifted }\end{array}$ \\
\hline
\end{tabular}

Table 4: BDA test result scores 